Центр Российских Исследований

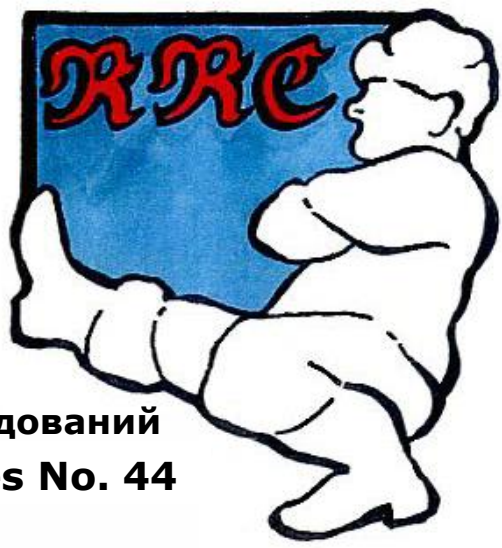

Foreign Direct Investment and Regional Economic

Development in Russia: An Econometric Assessment

Ichiro IWASAKI and Keiko SUGANUMA

June 2014: first version

April 2015: revised version

\author{
RUSSIAN RESEARCH CENTER \\ INSTITUTE OF ECONOMIC RESEARCH \\ HITOTSUBASHI UNIVERSITY \\ Kunitachi, Tokyo, JAPAN
}


RRC Working Paper No. 44

April 2015 [revised version; first published in June 2014]

\title{
Foreign Direct Investment and Regional Economic Development in Russia: An Econometric Assessment ${ }^{\dagger}$
}

\author{
Ichiro Iwasaki $\mathrm{i}^{\mathrm{a}}$ and Keiko Suganuma ${ }^{\mathrm{b}}$ \\ a Institute of Economic Research, Hitotsubashi University, Tokyo, Japan \\ ${ }^{\mathrm{b}}$ College of Bioresource Sciences, Nihon University, Kanagawa, Japan
}

\begin{abstract}
In this paper, we estimate the effect of foreign direct investment (FDI) on total factor productivity (TFP) in Russian regions, paying special attention to the country's investment boom and the remarkable regional gaps in terms of cumulative direct investments in and after 2003. We also examine possible synergistic effects between FDI and local R\&D potential to test the absorptive capacity hypothesis. Our estimation results strongly suggest the remarkable role of FDI in the regional economic development in Russia. In addition, we found that the positive effect of FDI on TFP may increase in the regions that received larger amounts of foreign capital. Furthermore, we detected a surprisingly robust and positive synergistic effect between FDI and local R\&D potential, indicating that the absorptive capability is essential for linking FDI and regional economic development in Russia.
\end{abstract}

JEL classification numbers: F21, O11, P25, P33, R11

Key words: foreign direct investment (FDI), regional economic development, total factor productivity, R\&D potential, absorptive capacity hypothesis, Russia

\footnotetext{
$\dagger$ This research was financially supported by Grant-in-Aids for scientific research from the Ministry of Education and Sciences of Japan (Nos. 23243032; 26245034) and the College of Bioresource Sciences of Nihon University. We thank George Hondroyiannis and Masahiro Tokunaga as well as participants in the 54th National Congress of the Japanese Association for Comparative Economic Studies at Yamaguchi University, Yamaguchi, June 7-8, 2014, and the 13th EACES (European Association of Comparative Economic Studies) biennial conference at Corvinus University of Budapest, September 4-6, 2014, for their helpful comments and suggestions. We also would like to thank Tammy Bicket and Shigeo Yamazaki for their editorial assistance. Needless to say, all remaining errors are solely our responsibility.

$\$$ Corresponding author: 2-1 Naka, Kunitachi City, Tokyo 186-8603, JAPAN; Tel.: +81-42-580-8366; Fax: +81-42-580-8333; E-mail address: iiwasaki@ier.hit-u.ac.jp
} 


\section{Introduction}

In 2012, a series of important events took place in Russia that highlighted the country's integration with the global economy. First, Russia officially joined the World Trade Organization (WTO) in August. It took the country more than 18 years to achieve this national goal; the Russian federal government applied to join the General Agreement on Tariffs and Trade (GATT), the predecessor of the WTO, in 1993. Second, Russia hosted a summit meeting of the AsiaPacific Economic Cooperation (APEC) in Vladivostok in September for the first time. The summit meeting culminated in a declaration by the leaders outlining the agreements, which included the liberalization of trade investment and regional economic integration, the establishment of a reliable supply chain, as well as close cooperation so as to achieve innovative growth. ${ }^{1}$ Furthermore, Russia launched the Common Economic Space with Belarus and Kazakhstan in January of the same year as a developed version of their customs union. This series of policy events is expected to accelerate not only trade activities between Russia and foreign counties but also movement of capital and to contribute significantly to the development of the Russian economy.

It is widely believed that capital investments by foreign investors and multinational enterprises bring positive economic effects to recipient countries in various ways. For this reason, policymakers of post-communist states and developing countries that face a lack of capital or technological expertise proactively invite foreign direct investment (FDI) and direct efforts to develop their countries on the basis of FDI. The actions of these countries have stimulated in economists a keen interest in conducting research into how and to what extent FDI impacts the economies of the recipient countries, and they are conducting a variety of empirical analyses to determine the mechanisms involved. It is not too much to say that the accumulated volume and scope of this kind of research is now quite large. However, work on post-communist transition economies accounts for a very small proportion of earlier studies, and the majority of these focus on some Central and Eastern European (CEE) countries that joined the European Union (EU), with only a minority of studies focusing on Russia and the other countries of the former Soviet Union (FSU) (Iwasaki and Tokunaga, 2014).

Meanwhile, Russia, as one of the five large and fast-growing economies of BRICS, sees its economy growing and its private consumption booming in tandem with an increase in national income. In fact, the Russian economy reported an average annual growth of $6.9 \%$ for the ten years ending in 2009 after the country resolved its domestic financial crisis of 1998, during

1 See the website of the Ministry of Economy, Trade and Industry of Japan (http://www.meti.go.jp/policy/trade_policy/apec/ index.html). 
which its economy was affected by the global financial crisis and temporarily slowed. As Table 1 shows, during this period, industrial production was also strong, consumer prices and the unemployment rate remained relatively stable, and, moreover, the country enjoyed a growing trade surplus. ${ }^{2}$ Against the background of such brisk growth trends, direct investments from various nations increased sharply after 2003. At the end of the 2000s, Russia emerged as the largest recipient of FDI among the CEE and FSU countries, leading the others by a wide margin. ${ }^{3}$ Therefore, a strong correlation between Russia's remarkable economic development and significant FDI inflow is highly possible. We consider it very meaningful to empirically examine this point.

However, the observation period is currently far too short to examine the relationship between inward FDI and economic development in Russia by time-series analysis using national-economic level data. Therefore, in this paper, we approach this issue by empirically testing the effect of FDI on the total factor productivity (TFP) of the constituent entities of the Russian Federation. Ahrend (2005, 2008), Brock (2005), and Ledyaeva and Linden (2008) represent major earlier studies in this field. As we will report later, however, none has successfully verified a statistically significant effect of FDI in the Russian regions in their baseline estimations. A possible reason is that the estimation period in these previous works was limited to the early 2000s and, therefore, did not cover the large wave of FDI in 2003 and beyond. Moreover, although several microeconomic studies, including Brown and Earle (2000) and Yudaeva et al. (2003), verified the significant and positive effects of FDI in Russia, such a firmlevel empirical analysis has become extremely difficult due to current strong restrictions on access to the official data. In order to overcome these research shortcomings and restraints, we empirically examine the effect of FDI on TFP by using unique panel data of 71 Russian regions, paying special attention to the investment boom in 2003 and onward, as well as to the significant

2 According to the official data published by the Russian statistical office (http://www.gks.ru/), real GDP grew by $4.3 \%$ in 2011 and by $3.4 \%$ in 2012, recording a similar level in 2010 . However, the real GDP growth rate fell to $1.3 \%$ in 2013 , indicating a sharp decline in the country's sustained economic growth. In addition, the forcible accession of the Crimean Peninsula into the Russian Federation in the wake of Ukraine's political turmoil in March 2014 and the subsequent ongoing political conflict between the two nations have substantially worsened relations between Russia and major developed countries as well, which is highly likely to cause the growth rate of the Russian economy to deteriorate.

3 In fact, data published by the United Nations Conference on Trade and Development (UNCTAD) (http://unctadstat.unctad.org/) show that the cumulative gross direct investment in Russia from 1989-2009 was 23.57 billion USD higher than the amount received by Poland, which was ranked second among the $28 \mathrm{CEE}$ and FSU countries. 
regional gap in terms of cumulative investments during the same period.

Here, we also attempt to estimate the synergistic effect between FDI and local R\&D potential to test the absorptive capacity hypothesis in the context of the Russian regions. Lapan and Bardhan (1973) advanced the absorptive capacity hypothesis, which theoretically formulated the proposition that companies need to have a certain level of absorptive capability to benefit from a new technology developed by another company. This theory was further advocated by Borensztein et al. (1998), who applied the above proposition to the relationship between FDI and economic growth in a recipient country and concluded that there absolutely must be human capital capable of acquiring and applying advanced technologies in order to enable FDI to bring about higher productivity in the host economy. It is worthwhile to examine whether the absorptive capacity hypothesis is valid in Russia, which boasts excellent human capital even by international standards, although the country has fallen behind advanced economies in terms of production technologies. To the best of our knowledge, no study has tackled in earnest this issue in the context of the Russian regions. We will make a contribution to the literature from this viewpoint as well.

The estimation results reported in this paper strongly suggest the remarkable role of direct investment in regional economic development in Russia. In addition, we found that the positive effect of FDI on TFP may increase in the regions that received larger amounts of foreign capital. Furthermore, we detected a surprisingly robust and positive synergistic effect between FDI and local R\&D potential, indicating that the absorptive capability is essential for linking FDI and regional economic development in this country. This empirical evidence implies that the latest political collision between Russia and the international community over Ukraine may cast a shadow over Russian regional development through the significant decline of FDI inflow.

The remainder of this paper is organized as follows: In the next section, we highlight the basic trends of FDI in Russia during the period between 1995 and 2011 and review related literature to discuss issues for our empirical analysis. In Section 3, we explain our empirical methodology for verifying the TFP-enhancing effect of FDI in the Russian regions, and, then, in Section 4, we report our results. In Section 5, we test the absorptive capacity hypothesis. In Section 6, we report the statistical robustness of the estimation results. Finally, in Section 7, we summarize the major findings and conclude the paper.

\section{Statistical Overview of FDI in Russia from 1995-2011 and Literature Review}

We begin with an overview of FDI in Russia for the 17 years between 1995 and 2011 based upon statistical data provided by the Russian Federal State Statistics Service (Rosstat). Basic 
characteristics of direct investment in Russia as related to its regional economy can be summarized by the following four points:

First, as illustrated in Table 1, FDI in Russia was generally small between 1995 and 2002, falling short not only of the amount invested in Poland - the largest recipient country in the CEE region - but also of that in the Czech Republic or Hungary. This sluggish trend, however, was significantly improved after 2003. In fact, inward direct investment in Russia reached an average of 16.2 billion USD per year from 2003-2011, as compared to an average of 3.7 billion USD per year from 1995-2002. As a result, the cumulative direct investment for the period from 2003-2011 amounted to 145.9 billion USD or 5.7 times more than for the previous eight years. Such a drastic change points to a fundamental shift in the presence of foreign capital in the Russian economy.

Second, despite a sharp increase in FDI in and after 2003, Russia still lags behind many of the CEE countries in terms of the investment per capita. According to Table 1, the cumulative FDI per capita was a meager 1,230 dollars in Russia for the 17 years starting in 1995, which is much less than half the amount of that for the Czech Republic and Hungary. ${ }^{4}$ In other words, although Russia is now the largest recipient of FDI among the CEE and FSU countries, the amount invested is relatively small for the size of its national economy. This means that the impact of FDI on the Russian economy may be limited both at the national and regional levels, despite the investment boom in recent years.

Third, it is evident that FDI in Russia tended to be biased toward specific industries throughout the observation period. Table 2 reports the industrial breakdown of FDI in Russia from 2004-2008. As shown in this table, the fuel and energy industry accounted for $33.5 \%$ of the total investment for those five years, while real estate and rental services reported $14.4 \%$, and wholesale and retail trade plus repair services amounted to $10.8 \%$. The combined share of these three industries totaled $58.7 \%$. In contrast, the manufacturing industry, including all 14 subsectors, accounted for only $23.7 \%$ of the total. This does not represent a strict comparison, as the Rosstat significantly modified the country's industrial classification system in 2004 to make it more in line with international standards. However, given the fact that, during the period of $1995-2003$, about $16 \%$ of the total FDI went into the fuel and energy industry, some $18 \%$ benefitted the retail and restaurant industry, and about $30 \%$ was allocated to the food and other manufacturing industries, ${ }^{5}$ it appears that foreign investors and multinational enterprises that entered the Russian market in recent years limited their investments to securing abundant natural

4 Calculated by the authors using data provided by the UNCTAD

5 See Table 7 in Iwasaki and Suganuma (2005, p. 168). 
resources or to real estate trading or commercial activities for which the investments can be recovered in a relatively short period of time. In contrast, investors have been more wary than ever of investing in manufacturing industries. Lack of interest by foreign investors in manufacturing activities in Russia due to the high risks associated with long-term investments implies that technology transfer may not be fully achieved through FDI in this country.

Fourth, there remains a stark difference in terms of investments received among Russian regions even after 2003 when FDI increased sharply. In fact, as Panel (a) of Table 3 shows, Moscow, which was ranked first in cumulative FDI among the 71 constituent entities of the Russian Federation between 2003 and 2011, received 21,151 times more than did the Altai Republic, which ranked last. Similarly, Panel (b) of the same table illustrates that the Sakhalin Region, which ranked first in terms of cumulative investment per capita, enjoyed a rate 4,823 times higher than that of the Republic of Mari El at the bottom of the ranking. ${ }^{6}$ The mean and the standard deviation of cumulative FDI are 2,049.3 million USD and 6,559.0 million USD, respectively, while the mean and the standard deviation of the cumulative investment per capita is 1,300.7 USD and 5,761.7 USD, respectively. Accordingly, the coefficient of variation becomes 3.20 for the former and 4.43 for the latter, suggesting that the difference in the total amount of FDI received by the 71 regions is much wider when the population size of each region is taken into account. Moreover, there were only 20 regions that received FDI of more than 1 billion USD, and only 15 regions reported amounts invested per capita of greater than 1,000 USD during the same period. Therefore, we presume that there was a very limited number of Russian regions in which FDI could have had a significant impact on economic development.

Meanwhile, we found a total of 11 articles that examined the effect of FDI on the Russian economy using a quantitative method. Table 4 outlines these studies. In general, most macroeconomic studies failed to detect any statistically robust and significant effect of FDI. Moreover, most studies focusing on the Russia regions, including Ahrend (2005, 2008), Brock (2005), and Ledyaeva and Linden (2008), found a significant effect of FDI only after imposing certain restrictions on the estimation period or the regions to be analyzed. On the other hand, many microeconomic studies, represented by Brown and Earle (2000) and Yudaeva et al. (2003), could verify the effects of foreign ownership and productivity spillovers from foreign companies to domestic firms. In recent years, however, as the Rosstat has sharply restricted access by outsiders (even for academic purposes) to individual sets of data that form the basis of the official statistics, the possibility of firm-level empirical analyses using the official data has become

6 The Russian Federation is comprised of 83 constituent entities. However, 12 remaining regions, including those politically unstable in the North Caucasus Federal District, do not appear in Table 3, mainly due to data availability. 
extremely limited.

Based on the FDI trends in Russia during the period from 1995-2011 and an overview of the studies described above, it may be helpful to consider the following points for empirically reexamining the impact of FDI on the Russian regions:

First, the previous literature listed in Table 4 hardly examines the effect on the Russian economy of the big wave of FDI in and after 2003, mainly due to the studies' timing, with the exception of Dolgopyatova (2009). As we pointed out, it is highly likely that the presence of foreign capital significantly increased in the Russian economy during this period. Hence, an empirical analysis with an estimation period extending beyond 2003 may have a greater likelihood of identifying a statistically significant FDI effect than would studies focusing on a period prior to 2003. On the other hand, given the lower amount of direct investment in Russia than in the CEE countries in terms of per capita FDI and the strong investment bias toward certain industries, it is possible that it is still difficult to empirically verify the macroeconomic effect of FDI, even during the investment boom of 2003 and beyond.

The persistent FDI gap between the Russian regions is the second important point to be considered. As shown in Table 3, Russia has many regions that have attracted only small amounts of foreign capital. It is unreasonable to expect these regions, such as the small autonomous republics in remote areas, to have enjoyed a sufficient macroeconomic effect from FDI to be captured by quantitative analysis. Ledyaeva and Linden (2008) successfully estimated a statistically significant FDI effect by dividing the regions into high-income and low-income groups. It may be an effective empirical strategy to examine the influence of the regional investment gap on the marginal effect of FDI by classifying the regions to be analyzed in terms of the total amount of actual investment or by another method.

In the following sections, we conduct an empirical analysis of FDI's effect on regional TFP, taking into account the two points described above.

\section{Empirical Methodology}

In accordance with the first issue discussed in the previous section, we estimated a regionallevel production function using long-term panel data that cover the period of the investment boom in and after 2003. In response to the second issue, we also performed an estimation of an extended model designed to examine the possible influence of the regional investment gap on the effect of FDI, in addition to the baseline estimation.

More specifically, we conducted a panel data estimation of a Cobb-Douglas production function, taking the real gross regional product (GRP) of the $i$-th Russian region in the year $t$ as 
a dependent variable:

$$
G R P_{i, t}=\mathrm{F}\left(A_{i, t}, K_{i, t}, L_{i, t}\right)=A_{i, t} K_{i, t}^{\alpha} L_{i, t}^{\beta},
$$

where $A$ represents TFP, $K$ and $L$ denote inputs of capital and labor, while $\alpha$ and $\beta$ are their output elasticities. By taking the logarithms of both sides and adding a disturbance term into the righthand side, we transform Equation (1) into the following linear model:

$$
\operatorname{lnGRP} P_{i, t}=a_{i, t}+\alpha \ln K_{i, t}+\beta \ln L_{i, t}+\varepsilon_{i, t}
$$

where $a=\ln A$, and $\varepsilon$ is a disturbance term. We assume that the first term on the right-hand side of Equation (2) is a function of FDI and other various factors that affect TFP of the Russian regions.

While the primary focus of our empirical analysis is the effect of FDI on regional TFP, the direction and extent to which foreign capital affects the productivity of the recipient regions are not theoretically clear. In fact, according to the endogenous growth theory, FDI directly and indirectly affects TFP in a recipient region as long as it brings improvements in technology systems and/or human capital to the region through the contributions of foreign participation in management, the establishment of local subsidiaries by multinational enterprises, the outsourcing of contracts between local and foreign firms, and so forth (Grossman and Helpman, 1991; Markusen and Venables, 1999; Iwasaki et al., 2012). Meanwhile, market-seeking FDI may hamper the growth of productivity in a host region due to its crowding-out effects through fierce competition between foreign and domestic firms (Ponomareva, 2000; Moran, 2005). Taking into account the weak management base and backward production technology of former socialist enterprises as compared with multinational corporations based in developed economies, it is highly likely that such negative external effects have taken place in Russia (Iwasaki and Tokunaga, 2014). In summary, as Castellani and Pieri (2011) argue, the effect of FDI and the entry of foreign multinationals on aggregate productivity in the host economy largely depend on the balance between the positive pecuniary and technological externalities and the sterling's negative effect on business. The impact of FDI is also affected by the type of activities that foreign companies transfer into the host economy. Therefore, it is possible that FDI works as a detrimental factor against aggregate productivity dynamics. In addition, theoretical consideration regarding the time-lag effect and the accumulation effect of direct investments is also insufficient.

For this reason, researchers have attempted to examine the effect of FDI on the recipient economies using a variety of FDI variables (Iwasaki and Tokunaga, 2014). Following the empirical strategy adopted in the previous literature, we also estimate a total of five types of FDI 
variables. They consist of (1) the natural logarithm of annual direct investments ( $\ln F D I A N N)$, (2) the natural logarithm of the three-year moving average of annual direct investments (lnFDI3AVE), (3) the natural logarithm of annual direct investments per capita (lnFDIPC), (4) the natural logarithm of cumulative direct investments ( $\ln C U M F D I$ ), and (5) the natural logarithm of cumulative direct investment per capita $(\ln C U M F D I P C)$. The estimation of these five different kinds of FDI variables may allow us to verify the time-lag and accumulation effects of FDI on regional TFP in Russia from multi-angle perspectives. Further, following Ledyaeva (2009) and Castellani and Pieri (2011), we have adopted predetermined variables reported for the previous year for all of the FDI variables, taking into consideration the possibility that foreign investment activities affect the production activities of the recipient regions with at least a one-year lag. Needless to say, the use of predetermined variables is effective for avoiding or mitigating the endogeneity bias between GRP and FDI.

We employed the following 10 variables as control variables to be simultaneously estimated with the FDI variables above: (1) the ratio of former state-owned (ex-municipal) privatized companies to the total number of companies (PRICOM), (2) the natural logarithm of the number of fixed telephones per thousand people (InTELEPHONE), (3) a dummy for large cities and areas adjacent to a large city (BIGCITY), (4) a dummy for regions with a large-scale port (BIGPORT), (5) a dummy for regions bordering Europe (EUROPE), (6) a dummy for the Pacific coastal regions (PACIFIC), (7) a dummy for resource-rich regions (RESOURCE), (8) the natural logarithm of the latest production technologies utilized (lnNEWTECH), (9) the natural logarithm of total fixed capital $(\ln F I X C A P)$, and (10) the natural logarithm of the annual average number of workers $(\ln L A B O R)$.

PRICOM is used as a proxy for the progress in economic liberalization, while InTELEPHONE is utilized to express the prevalence of the communication infrastructure. $B I G C I T Y$ is designed to capture the concentration effects of a large city and its spillover effects on the surrounding areas. BIGPORT is introduced to estimate the effects of trading activities with foreign countries on a region with large-scale port facilities. EUROPE and PACIFIC represent the geographical proximity to foreign markets. RESOURCE is employed to examine the effects of abundant natural resources on the development of a regional economy. InNEWTECH is adopted to capture the effects of local R\&D activity on promoting regional productivity. ${ }^{7}$ Along with the FDI variables, these eight variables are assumed to determine

${ }^{7}$ According to the Rosstat, the latest production technologies denote planning, production, and processing systems based on computer, microelectronic, and information sciences, comprising machines and equipment utilized for their realization. The typical case includes: an assembly robot and a flexible production center, as well as an automatic designing and controlling system operated 
regional-level TFP. The remaining, $\ln F I X C A P$ and $\ln L A B O R$, are proxy variables for capital and labor inputs, respectively. We predict that these controlling factors are positively correlated with the dependent variable together with the FDI variables. ${ }^{8}$

Table 5 provides more detailed definitions, described statistics, and a correlation matrix of the variables used for the panel data estimation. The dependent variable of $\ln G R P$ and other continuing variables are derived from the official statistics released by the Rosstat, while we set dummy variables based on materials available on the Internet. As this table shows, all of the correlation coefficients of the independent variables that were simultaneously estimated are below 0.70 , the threshold of possible multicollinearity (Lind et al., 2004).

The panel regression equation, in which the individual effects of the $i$-th region and the time fixed effect of year $t$ are also controlled together with the independent variables listed in Table $\mathbf{5}$, is formulated as follows:

$$
\begin{aligned}
& \operatorname{lnGRP}_{i, t}=\mu+\beta_{1} \text { FDI }_{i, t-1}+\beta_{2} \text { PRICOM }_{i, t}+\beta_{3} \operatorname{lnTELEPHON} E_{i, t}+\beta_{4} \text { BIGCITY }_{i} \\
& +\beta_{5} \text { BIGPORT }_{i}+\beta_{6} \text { EUROPE }_{i}+\beta_{7} \text { PACIFIC }_{i}+\beta_{8} \text { RESOURCE }_{i} \\
& +\beta_{9} \operatorname{lnNEWTECH} H_{i, t}+\beta_{10} \operatorname{lnFIXCAP_{i,t}}+\beta_{11} \ln L A B O R_{i, t}+\varphi_{i}+\vartheta_{t} \\
& +\varepsilon_{i, t} \text {, }
\end{aligned}
$$

where $\mu$ is the constant term, $\beta$ is a parameter to be estimated, $\varphi$ denotes the individual effect on the Russian regions, and $\vartheta$ represents the time fixed effect.

To estimate Equation (3), we used panel data of the 71 Russian regions for the period from 1996-2011. The breakdown of these 71 regions is consistent with Table 3. Since some independent variables are constant during the observation period, we utilized a pooled OLS estimator or a random-effects estimator to obtain estimates for these time-invariant variables. We selected one of these two estimators for our estimation in accordance with the BreuschPagan test of the null hypothesis that the variance of the individual effects is zero. We set the critical value for this specification test at a 5\% significance level.

Although our basic empirical strategy is described above, following Castellani and Pieri

by a computer. The raw data are collected for all but small business enterprises through an enterprise questionnaire survey. The variate does not mean the total sum of employed machines and equipment but the number of realized technological systems as a whole. This variable comes much closer to the real circumstances of the production sites in Russian firms than do alternative R\&D-related variables, thus, suiting well the purpose of our research.

8 In selecting our independent variables, we referred to Popov (2001), Piliasov (2003), Solanko (2003), Benini and Czyzewski (2007), Brock (2009), Bajo-Rubio et al. (2010), Kirillova and Kantor (2011), Ledyaeva et al. (2012), and Kuzmina et al. (2014), in addition to the previous studies listed in Table 4. 
(2011), Gries and Redlin (2011), and Jiang (2012), we also estimated a system generalized method-of-moments (GMM) dynamic model that adopts a non-lagged FDI variable and explicitly deal with its endogeneity with the dependent variable $\ln G R P$ in order to check the statistical robustness of the FDI variables. ${ }^{9}$

\section{Estimation Results}

Table 6 presents the baseline estimation of Equation (3). Models [1] to [5] are estimation results in accordance with the basic empirical strategy, and Models [6] to [10] report those of the system GMM dynamic models. The Breusch-Pagan test rejects the null hypothesis for all of the first five models at the $1 \%$ significance level. Therefore, we have reported the results of the randomeffects estimation. The coefficient of determination $\left(R^{2}\right)$, which represents the explanatory power of an entire model, is above 0.90 in all five random-effects models ( 0.91 on average), suggesting that they sufficiently explain the variance of the real GRP in the Russian regions. With regard to the system GMM dynamic models, we cannot conduct the Sargan test of overidentifying restrictions with robust standard errors. However, according to the test results that use estimates with normal standard errors, the null hypothesis that overidentifying restrictions are valid is accepted for all models [6] to [10]. In addition, the Arellano-Bond test for $\operatorname{AR}(2)$ also accepts the null hypothesis of no autocorrelation for all five models. ${ }^{10}$

Consistent with our prediction described in Section 2, it is likely that the role of foreign capital in the Russian economy increased greatly throughout the period in and after 2003 when FDI grew sharply. In fact, as the random-effects models in Table 6 show, unlike most of the earlier studies, which do not cover this investment boom in their observation periods, the threeyear moving average of annual direct investments ( $\ln F D I 3 A V E)$, the cumulative direct investments ( $\ln C U M F D I)$, and the cumulative direct investments per capita (lnCUMFDIPC) are estimated to be positive and statistically significant; furthermore, the significance level of the latter two variables reached $1 \%$, implying an extremely strong correlation with the dependent variable. These results underline the considerable importance of FDI as a determining factor for the economic development of the Russian regions.

On the other hand, although the regression coefficient of annual direct investments $(\ln F D I A N N)$ and annual direct investments per capita $(\ln F D I P C)$ also show positive signs, along

\footnotetext{
9 To estimate the system GMM dynamic model, we assumed a two-year lag structure of the FDI variable.

10 Although we do not mention it hereafter due to space limitations, the same model specification test results apply for all of the regression analyses reported in Table 7 and Section 5.
} 
with the above three variables, their statistical significance is below the $10 \%$ level. This implies that the input of direct capital from various foreign countries contributes to the Russian regions, not as much in short-term as through long-term and cumulative improvements in TFP. The system GMM dynamic models, however, show significant and positive coefficients of $\ln F D I A N N$ and $\ln F D I P C$ together with $\ln C U M F D I$ and $\ln C U M F D I P C$. Although these results strongly suggest the presence of the accumulation effect of foreign capital inflow on TFP in Russian regions, they do not enable us to evaluate the time-lag effect of FDI.

Among the control variables, RESOURCE, which represents the natural resource abundance, shows a robust and positive effect on regional TFP, along with $\ln F I X C A P$ and $\ln L A B O R$, in line with our predictions. Both EUROPE and PACFIC, the dummy variables for regions bordering Europe and for Pacific coastal regions, respectively, show significant and positive estimates in Models [1] to [3]. However, given that the coefficient and the statistical significance of the latter greatly exceed those of the former, the economic significance of the proximity to foreign markets is likely to differ sharply between Russian regions bordering Europe and Asia. The fact that the federal government has increased interest in forging economic ties with high-growth Asian economies to shore up the Far East region in recent years is not without reason, from this perspective.

PRICOM, the ratio of former state-owned (ex-municipal) privatized companies to all of the companies, and InTELEPHONE, the number of fixed telephones per thousand people, are estimated with a positive sign in all of the models; however, their statistical significances are below the $10 \%$ level, except for the latter variable in Model [6]. Moreover, the estimates of BIGCITY and BIGPORT are also insignificant, indicating that the geographical factors of being a large city or a port region are actually not important factors for the productivity increase in the Russian regions. InNEWTECH also shows insignificant estimates, implying that local R\&D activity itself is not bringing remarkable improvements to TFP in the regional economy. These results strongly suggest that a series of policy issues, including overcoming regional fragmentation through deepening economic ties between large cities and their surrounding regions, revitalizing port regions by promoting foreign trade, and improving the efficiency of domestic R\&D activities, are far from complete.

In Table 7, we examine the relationship between the investment gaps among Russian regions and the effect of FDI. Panel (a) of the table shows the estimation results, in which the observations are limited to the top 35 regions in terms of the cumulative FDI per capita from 2003-2011. As seen in this panel, the sign and the effect size of the statistically significant FDI variables do not differ remarkably from those of the baseline estimation reported in Table 6, and, although the coefficient of $\operatorname{lnFDI3AVE}$ in the random-effects model and $\ln C U M F D I P C$ in the 
system GMM dynamic model remained positive, their statistical significance levels fall to more than $10 \%$. These results suggest that the effects of FDI on regional TFP are not necessarily limited to the regions that have attracted relatively large amounts of foreign capital. As indicated in Panels (b) and (c) of Table 7, however, the interaction terms of an FDI variable and the dummy variable for the top 35 regions as well as the squared terms of an FDI variable are estimated to be significant and positive in 14 of the 20 models. ${ }^{11}$ This finding entails the possibility of a mild non-linear correlation between the size of FDI and its TFP enhancing effect in the Russian regions.

\section{Examination of the Absorptive Capacity Hypothesis}

In order to enable FDI to enhance productivity in the host economy, advanced knowledge and technology that will be introduced from abroad in the wake of a capital investment must be actually applied to management practices as well as production activities on site. In this case, refinements and changes are often required in response to local-specific circumstances and/or conditions; hence, these requirements demand at least a certain level of comprehension and applied skill on the part of economic entities in the recipient country. The case is much more relevant to domestic firms that strive to improve their productivity by observing and following foreign companies (Iwasaki et al., 2012). In sum, the feasibility of technology transfer from FDI is positively correlated with the absorptive capability of the host economy (Girma, 2005).

The above paragraph describes the basic idea of the absorptive capacity hypothesis that we mentioned in the Introduction. There seems to be little room for any counterargument. Nevertheless, not all preceding studies have presented evidence that supports this hypothesis (Crespo and Fontoura, 2007). In addition, several studies of the CEE economies have examined the relationship between the productivity-enhancing effect of FDI and the absorptive capability of the recipient country, and their empirical results are far from consistent (Campos and Kinoshita, 2002; Altomonte and Pennings, 2009; Bijsterbosch and Kolasa, 2010; Nicolini and Resmini, 2010; Damijan et al., 2013; Neycheva, 2013). Moreover, with regard to Russia, as mentioned in Table 4, Brock (2005) has estimated the interaction term of the percentage of change in the cumulative amount of FDI to GRP relative to the prior year and the number of secondary school students per 10,000 residents in order to test a possible synergistic effect between FDI and human capital. However, his empirical results have failed to support the absorptive capacity hypothesis, as the regression coefficients are insignificant in the baseline

\footnotetext{
${ }^{11}$ Although the estimates of the control variables are not reported in Table 7, they are not so different from those in the baseline estimation.
} 
estimation, and they are rather significant and negative in the subsample estimation, using the observations of corrupted regions.

As shown above, with regard to the validity of the absorptive capacity hypothesis, the conclusions obtained from earlier studies are mixed. One reason is that these empirical results largely depend on the method of measuring the absorptive capability of the host economy (Liu and Nishijima, 2013). From this viewpoint, Todo and Miyamoto (2006), Fu (2008), Lööf (2009), and Huang et al. (2012), all of which have stressed the role of R\&D activities as an intermediate factor of technology transfer, are noteworthy. Therefore, in this paper, we will use R\&D potential as a proxy for the absorptive capability of Russia instead of the average education level in the recipient country, which has been adopted by many preceding studies on developing economies, in order to reexamine the absorption capacity hypothesis in the case of the Russian regions. As is well known, Russia experienced considerable downsizing of R\&D activities due to economic stagnation and other difficulties during its transition period. Nevertheless, this country still maintains one of the world's largest groups of R\&D experts as well as enormous R\&D facilities inherited from the Soviet Union. The problem is that such a large scale of R\&D capital has not necessarily been utilized by the private business sector in an effective manner (Algieri, 2006; Yegorov, 2009; Gutierrez and Correa, 2012). This notion is also consistent with the empirical results we reported in the previous section, which show insignificant estimates of the natural logarithm of the latest production technologies utilized (InNEWTECH).

If these domestically excessive $R \& D$ facilities and related human resources are effectively combined with the advanced knowledge and technology introduced by foreign capital, FDI might be capable of enhancing productivity in the relevant recipient regions without causing fierce competition with local firms. Moreover, as mentioned below, Russia's R\&D potential is far from being geographically homogeneous; rather, there is uneven distribution among the regions. This fact infers that the feasibility of linking FDI and R\&D potential may differ substantially between the regions; thus, this factor is likely to have a certain effect on regional TFP. This is why we have focused on local $R \& D$ potential to examine the absorptive capacity hypothesis in the context of the Russian economy.

As is the case with domestic firms, it is obviously true that foreign companies have insufficient connections with the local R\&D sector (Dyker, 2004). However, this does not mean that FDI has no tendency to move to local regions with high R\&D potential. As seen from Panel (a) of Figure 1, in which the natural logarithm of annual direct investments (lnFDIANN) is plotted on the vertical axis and the natural logarithm of the latest production technologies utilized ( $\ln N E W T E C H)$ is plotted on the horizontal axis, a moderate positive correlation between the two can be observed. A similar tendency can also be confirmed in the other panels of the 
same figure, in which the natural logarithm of technological innovation costs per R\&D staff member (InINNOVCOST), the natural logarithm of the total number of research and higher education institutions (InINSTITUTE), and the natural logarithm of the number of higher education school students per 10,000 residents (InSTUDENT) have been adopted as alternative variables to $\operatorname{lnNEWTECH}$. Moreover, Figure 1 also shows that the variance of these four R\&D variables is quite large and, consequently, suggests significant regional disparity in R\&D potential as the cause of the regional distribution of FDI.

The absorptive capacity hypothesis can be tested by estimating the interaction term of an FDI variable and a proxy variable for the absorptive capability. Therefore, we have introduced the interaction term of the FDI variable and the InNEWTECH variable into the right-hand side of the regression equation and re-estimated it with the other conditions in the baseline estimation being the same. Table 8 shows the results. As shown in this table, the interaction term is positive and significant at a level of $5 \%$ or less in all ten models, irrespective of the difference in the definition of the FDI variable and the estimator. These results strongly suggest that a very remarkable TFP-promoting synergistic effect between FDI and local R\&D potential prevails in the Russian regions. Meanwhile, as is the case with the estimation results of Borensztein et al. (1998), Table 8 reveals that all of the statistically significant estimates of FDI variables have a negative sign, indicating that FDI may cause a net negative effect on the aggregate productivity in a region where the linkage between foreign companies and the local $R \& D$ sector is very weak. ${ }^{12}$

How many regions are actually faced with a net negative effect of FDI in Russia? According to the random-effects model [5] in Table 8, the negative direct effect of FDI and the positive synergistic effect between FDI and local R\&D potential offset each other, and, hence, the total effect of FDI becomes zero in a region where the number of the latest production technologies utilized is only 56.5. Table 9 shows that, in 2011, the Republic of Tuva is the sole region under this threshold and, accordingly, the rest of the 70 regions enjoy a positive FDI effect on TFP in the net term. Based upon this result, we surmise that direct investment from foreign economies positively influences productivity in almost all of the Russian regions.

In order to check the statistical robustness of the synergistic effect between FDI and local R\&D potential, we also performed another set of estimations, using alternatives to the InNEWTECH variable as presented in Figure 1. The results, shown in Table 10, show that each

${ }^{12}$ In addition to the FDI variable, the $\operatorname{lnNEWTECH}$ variable is estimated to be negative and significant in six out of ten models. We conjecture that, in Russia, R\&D facilities and the related human resources are more likely to become burdens on the regional economies unless they are effectively connected to the business activities of foreign companies. 
interaction term of the FDI variable and each of the three kinds of $R \& D$ variables show positive and significant coefficients in 24 of the 30 models, suggesting that the combination of FDI and R\&D capital has a very powerful synergistic effect on regional TFP. To summarize, the empirical results in this section strongly support the validity of the absorption capacity hypothesis in the Russian regions.

\section{Additional Robustness Check}

In the previous two sections, we have consistently exhibited the estimation results of the random-effects model according to the basic empirical strategy described in Section 3. In this regard, we report that the Hausman test accepts the null hypothesis of the random-effects assumption in most cases; additionally, in a few cases when the Hausman test rejected the null hypothesis, we performed a fixed-effects estimation and compared its result with the randomeffects estimation and did not find any significant differences between the two. As another robustness check, we also conducted estimation of a first-difference model, a population-average model, and a between-effects model and found no noteworthy differences from the randomeffects models and/or the system GMM dynamic models reported in Tables 6, 7, 8, and 10. These findings lead us to the conclusion that the empirical results in this paper are robust across the various specifications.

\section{Conclusions}

As illustrated by Russia's accession to the WTO in August of 2012 after more than 18 years of long negotiations and a series of other policy events in recent years, the country has been steadily bolstering its economic ties with the international community. As reported in Table 1, direct investments from abroad into Russia increased remarkably in and after 2003, fully demonstrating its power as an emerging market.

Now that Russia is becoming dynamically integrated into the global economy, the role foreign capital plays in developing the Russian economy is certainly attracting interest among policymakers and economists. This is because, as pointed out in Section 2, there is still ample room for Russia to attract more FDI and for multinational enterprises to establish their bases in this country, given the size of its national economy, although Russia is already the largest recipient of FDI among the CEE and FSU countries. The number of empirical studies regarding Russia's economic development in relation to FDI is currently very limited, and most macroeconomic and regional-level studies have failed to find the positive relation between these two elements. In this paper, we have attempted to re-examine the TFP-enhancing effect of FDI 
in the Russian regions by conducting a unique panel data analysis.

More specifically, we estimated the Cobb-Douglas production function that takes real GRP as a dependent variable, using panel data covering a total of 71 regions for the period of 19962011. As a result, we found a close relationship between FDI and regional TFP in Russia. In fact, according to our baseline estimation, three out of the five FDI variables in the random-effects estimation and four in the system GMM estimation show statistically significant and positive coefficients (Table 6). In particular, the cumulative direct investment ( $\ln C U M F D I)$ variable is repeatedly estimated to be significant and positive, even when the observations are limited to the top 35 regions in terms of cumulative FDI per capita from 2003-2011 (Panel (a) of Table 7). These results strongly suggest the long-term and cumulative impact of FDI on TFP in the recipient regions. Considering that the previous regional-level studies, including Ahrend (2005, 2008), Brock (2005), and Ledyaeva and Linden (2008), were not successful in detecting a statistically significant effect of FDI in their baseline estimations, we think that it is a useful empirical strategy to extend the observation period more broadly to include the years after 2003 from the viewpoint of increasing the amount of information and our arguments as described in Section 2.

In this paper, we also examined the absorption capacity hypothesis. As shown in Tables 8 and 10, with regard to the interaction term of the FDI variable and a proxy variable for local R\&D potential, as many as 34 cases out of 40 different combinations have repeatedly shown positive and significant coefficients. These surprisingly robust estimates strongly demonstrate the validity of the absorption capacity hypothesis in the Russian regions. Based on these findings, we maintain that the enhancement of collaboration between foreign companies and the domestic $\mathrm{R} \& \mathrm{D}$ sector is an extremely important policy issue for Russia.

Moreover, our estimation results suggest that a series of geographical factors, such as the size of cities and the existence of a port region, did not provide sufficient productivity-promoting effects in the Russian regions, while geographical proximity to foreign markets and the abundance of natural resources contributed significantly to the improvement of regional productivity, in line with our predictions. In order to achieve balanced and dynamic economic development in the Russian regions, we hope that policymakers will attract FDI more proactively through further market liberalization and deregulation and promote ties between the R\&D sector and foreign multinationals, while formulating and executing policy measures that will address the various economic problems implied in our empirical evidence without delay. ${ }^{13}$

13 From the viewpoint of attracting more FDI and promoting mutual cooperation between the domestic R\&D sector and foreign companies, tighter state control over so-called strategic industries and diplomatic tensions with Western developed countries over political rights and 


\section{References}

Ahrend R (2005) Speed of reform, initial conditions or political orientation? explaining Russian regions' economic performance, Post-Communist Economies 17: 289-317.

Ahrend R (2008) Understanding Russian regions' economic performance during periods of decline and growth: an extreme bound analysis approach, Working Paper No. 644 ECO/WKP (2008) 52, Paris, OECD.

Algieri B (2006) Human capital in Russia, European Journal of Comparative Economics 3: 103-129.

Altomonte C, Pennings E (2009) Domestic plant productivity and incremental spillovers from foreign direct investment, Journal of International Business Studies 40: 1131-1148.

Bajo-Rubio O, Díaz-Mora C, Díaz-Roldán C (2010) Foreign direct investment and regional growth: an analysis of the Spanish case, Regional Studies 44: 373-382.

Benini R, Czyzewski A (2007) Regional disparities and economic growth in Russia: new growth patterns and catching up, Economic Change and Restructuring 40: 91-135.

Bessonova E, Kozlov K, Yudaeva, K (2003) Trade liberalization, foreign direct investment, and productivity of Russian firms, Working Paper No. 39, Centre for Economic and Financial Research at New Economic School - CEFIR, Moscow.

Bijsterbosch M, Kolasa M (2010) FDI and productivity convergence in Central and Eastern Europe: an industry-level investigation, Review of World Economics 145: 689-712.

Borensztein E, De Gregorio J, Lee J-W (1998) How does foreign direct investment affect economic growth? Journal of International Economics 45: 115-135.

Broadman H G (2000) Reducing structural dominance and entry barriers in Russian industry, Review of Industrial Organization 17: 155-176.

Brock G (2005) Regional growth in Russia during the 1990s: what role did FDI play? PostCommunist Economies 17: 319-329.

Brock G (2009) Growth and foreign direct investment in American states, 1977-2001, Review of Urban and Regional Development Studies 21: 110-123.

Brown J D, Earle J S (2000) Competition and firm performance: lessons from Russia, Working Paper No. 296, William Davidson Institute, University of Michigan, Ann Arbor.

Campos N, Kinoshita Y (2002) Foreign direct investment as technology transferred: some panel evidence from the transition economies, The Manchester School 70: 398-419.

Castellani D, Pieri F (2011) Foreign investments and productivity: evidence from European regions, Quaderni del Dipartimento di Economia, Finanza e Statistica No. 83/2011, University of Perugia, Perugia.

Crespo N, Fontoura M P (2007) Determinant factors of FDI spillovers: what do we really know? World Development 35: 410-425.

Damijan J P, Rojec M, Majcen B, Knell M (2013) Impact of firm heterogeneity on direct and spillover effects of FDI: micro-evidence from ten transition countries, Journal of Comparative Economics 41: 895-922.

human rights issues send negative signals to foreign investors and multinational enterprises (Iwasaki and Suganuma, 2015). It is hoped that the Putin administration will modify its policies as soon as possible. In the same context, the political conflict with Ukraine from the spring of 2014 should be settled immediately. 
Dolgopyatova T (2009) Izmenenie struktupy sobstvennosti na predpriyatiyakh obrabatyvayushchei promyshlennosti (po dannym monitoringa), Voprosy Ekonomiki No. 12: 111-124 (in Russian).

Dyker D A (2004) Catching Up and Falling Behind: Post-Communist Transformation in Historical Perspective. Imperial College Press, London.

Fu X (2008) Foreign direct investment, absorptive capacity and regional innovation capabilities: evidence from China, Oxford Development Studies 36: 89-110.

Girma S (2005) Technology transfer from acquisition FDI and the absorptive capacity of domestic firms: an empirical investigation, Open Economies Review 16: 175-187.

Gries T, Redlin M (2011) International integration and the determinants of regional development in China, Economic Change and Restructuring 44: 149-177.

Grossman, G M, Helpman, E (1991) Innovation and Growth in the Global Economy. MIT Press, Cambridge, Mass.

Gutierrez J J, Correa P (2012) Commercialization of publicly funded research and development (R\&D) in Russia: scaling up the emergence of spinoff companies, Policy Research Working Paper No. 6263, World Bank, Washington, D.C.

Huang L, Liu X, Xu L (2012) Regional innovation and spillover effects of foreign direct investment in China: a threshold approach, Regional Studies 46: 583-596.

Iwasaki I, Csizmadia P, Illéssy M, Makó Cs, Szanyi M (2012) The nested variable model of FDI spillover effects: estimation using Hungarian panel data, International Economic Journal 26: 673709.

Iwasaki I, Suganuma K (2005) Regional distribution of foreign direct investment in Russia, PostCommunist Economies 17: 153-172.

Iwasaki I, Suganuma, K (2015) The impact of FDI and socio-cultural similarity on international trade: Poisson pseudo-maximum likelihood estimation of a Russian trade model, Economics Bulletin 35: 1020-1033.

Iwasaki I, Tokunaga M (2014) Macroeconomic impacts of FDI in transition economies: a metaanalysis, World Development 61: 53-69.

Jiang Y (2012) An empirical study of openness and convergence in labor productivity in the Chinese provinces, Economic Change and Restructuring 45: 317-336.

Kirillova S A, Kantor O G (2011) Regional growth: the quality of economic space, Regional Research of Russia 1: 199-209.

Kuzmina O, Volchkova N, Zueva T (2014) Foreign direct investment and governance quality in Russia, Journal of Comparative Economics 42: 874-891.

Lapan H, Bardhan P (1973) Localized technical progress and transfer of technology and economic development, Journal of Economic Theory 6: 585-595.

Ledyaeva S (2009) Spatial econometric analysis of foreign direct investment across Russian regions, World Economy 32: 643-666.

Ledyaeva S, Linden M (2008) Determinants of economic growth: empirical evidence from Russian regions, European Journal of Comparative Economics 5: 87-105.

Ledyaeva S, Karhunen P, Kosonen R (2012) The global economic crisis and foreign investment in Russia from the EU: empirical evidence from firm-level data, Eurasian Geography and Economics 53: 772-789.

Lind D A, Marchal W G, Wathen S A (2004) Statistical Techniques in Business and Economics. Twelfth Edition, McGraw-Hill, Irwin. 
Liu W, Nishijima S (2013) Productivity and openness: firm level evidence in Brazilian manufacturing industries, Economic Change and Restructuring 46: 363-384.

Lööf H (2009) Multinational enterprises and innovation: firm level evidence on spillover via R\&D collaboration, Journal of Evolutionary Economics 19: 41-71.

Markusen J R, Venables A J (1999) Foreign direct investment as a catalyst for industrial development, European Economic Review 43: 335-356.

Moran T H (2005) How does FDI affect host country development? using industry case studies to make reliable generalizations, in Moran T H, Graham E M, Blomström M (eds.) Does Foreign Direct Investment Promote Development? Institute for International Economics Center for Global Development, Washington, DC, 281-313.

Neycheva M (2013) Does higher level of education of the labor force cause growth? evidence from Bulgaria, Economic Change and Restructuring 46: 321-339.

Nicolini M, Resmini L (2010) FDI spillovers in new EU member states: which firms create them and which firms really benefit? Economics of Transition 18: 478-511.

Peter K S, Svejnar J, Terrell K (2004) Distance to the efficiency frontier and FDI spillovers, Discussion Paper No. 1332, Institute for the Study of Labor - IZA, Bonn.

Piliasov A (2003) Political and economic factors in the development of Russia's regions, Problems of Economic Transition 46: 32-55.

Ponomareva N (2000) Are there positive or negative spillovers from foreign-owned to domestic firms? Working Paper No. BSR/00/042, New Economic School, Moscow.

Popov V (2001) Reform strategies and economic performance of Russia's regions, World Development 29: 865-886.

Solanko L (2003) An empirical note on growth and convergence across Russian regions, Discussion Paper No. 9, Institute for Economies in Transition, Bank of Finland - BOFIT, Helsinki.

Todo Y, Miyamoto K (2006) Knowledge spillovers from foreign direct investment and the role of local R\&D activities: evidence from Indonesia, Economic Development and Cultural Change 55: 173-200.

Tytell I, Yudaeva K (2006) The role of FDI in Eastern Europe and New Independent States: new channels for the spillover effect, Working Papers No. 217, Centro Studi Luca D'agliano, Università Degli Studi Di Milano, Milano.

Yegorov I (2009) Post-soviet science: difficulties in the transformation of the R\&D Systems in Russia and Ukraine, Research Policy 38: 600-609.

Yudaeva K, Kozlov K, Melentieva N, Ponomareva N (2003) Does foreign ownership matter? Economics of Transition, 11: 383-409. 
Table 1. Selected macroeconomic indicators of Russia, 1995-2011

\begin{tabular}{|c|c|c|c|c|c|c|c|c|c|c|c|c|c|c|c|c|c|}
\hline & 1995 & 1996 & 1997 & 1998 & 1999 & 2000 & 2001 & 2002 & 2003 & 2004 & 2005 & 2006 & 2007 & 2008 & 2009 & 2010 & 2011 \\
\hline Gross domestic product (GDP) $(\%)^{\mathrm{a}}$ & -4.1 & -3.6 & 1.4 & -5.3 & 6.4 & 10.0 & 5.1 & 4.7 & 7.3 & 7.2 & 6.4 & 8.2 & 8.5 & 5.2 & -7.8 & 4.5 & 4.3 \\
\hline Industrial production $(\%)^{\mathrm{a}}$ & -4.6 & -4.5 & 2.0 & -5.2 & 11.0 & 8.7 & 2.9 & 3.1 & 8.9 & 8.0 & 5.1 & 6.3 & 6.8 & 0.6 & -9.3 & 8.2 & 4.7 \\
\hline Consumer price index $(\%)^{\mathrm{b}}$ & 131.3 & 21.8 & 11.0 & 84.4 & 36.5 & 20.2 & 18.6 & 15.1 & 12.0 & 11.7 & 10.9 & 9.0 & 11.9 & 13.3 & 8.8 & 8.8 & 6.1 \\
\hline Unemployment rate $(\%)^{\mathrm{c}}$ & 9.6 & 9.8 & 12.0 & 13.4 & 12.9 & 10.0 & 9.0 & 8.7 & 8.0 & 8.1 & 7.3 & 7.0 & 5.9 & 7.1 & 8.7 & 7.6 & 6.7 \\
\hline Trade balance (billion USD) & 31.5 & 38.7 & 32.0 & 27.7 & 42.6 & 69.2 & 58.1 & 60.5 & 76.4 & 106.0 & 142.8 & 163.4 & 152.1 & 200.5 & 134.4 & 168.2 & 211.0 \\
\hline Foreign direct investments (FDI) inflow (million USD) & 2,020 & 2,440 & 5,333 & 3,361 & 4,260 & 4,429 & 3,980 & 4,002 & 6,781 & 9,420 & 13,072 & 13,678 & 27,797 & 27,027 & 15,906 & 13,810 & 18,415 \\
\hline Cumulative FDI (million USD) $^{\mathrm{d}}$ & 2,020 & 4,460 & 9,793 & 13,154 & 17,414 & 21,843 & 25,823 & 29,825 & 36,606 & 46,026 & 59,098 & 72,776 & 100,573 & 127,600 & 143,506 & 157,316 & 175,731 \\
\hline Annual FDI inflow per capita (USD) ${ }^{\mathrm{e}}$ & 13.6 & 16.5 & 36.0 & 22.7 & 28.9 & 30.2 & 27.2 & 27.5 & 46.8 & 65.3 & 91.1 & 95.8 & 195.4 & 190.3 & 112.1 & 96.6 & 128.9 \\
\hline Cumulative FDI per capita (USD) ${ }^{\mathrm{d}, \mathrm{e}}$ & 13.6 & 30.1 & 66.2 & 89.0 & 118.0 & 148.7 & 176.5 & 204.8 & 252.5 & 319.3 & 411.9 & 509.8 & 707.2 & 898.5 & $1,011.3$ & $1,100.8$ & $1,230.0$ \\
\hline
\end{tabular}

Notes: ${ }^{\text {a }}$ Year-on-year real growth rate

Year-on-year change as of December

'Average unemployment rate of the working population (men aged 16-59 and women aged 15-54)

${ }^{\mathrm{d}}$ Total amount of inward FDI after 1995

${ }^{\mathrm{e}}$ Calculated based on the population as of January 1 of each year

Source: Russian Federal State Statistics Service (http://www.gks.ru/) 
Table 2. Sectoral breakdown of FDI in Russia, 2004-2008

\begin{tabular}{|c|c|c|c|c|c|c|c|c|c|c|c|c|}
\hline & \multicolumn{2}{|c|}{2004} & \multicolumn{2}{|c|}{2005} & \multicolumn{2}{|c|}{2006} & \multicolumn{2}{|c|}{2007} & \multicolumn{2}{|c|}{2008} & \multicolumn{2}{|c|}{$2004-2008$ total } \\
\hline & $\begin{array}{c}\text { Invested } \\
\text { amount } \\
\text { (million } \\
\text { USD) }\end{array}$ & $\begin{array}{c}\text { Share } \\
(\%)\end{array}$ & $\begin{array}{l}\text { Invested } \\
\text { amount } \\
\text { (million } \\
\text { USD) }\end{array}$ & $\begin{array}{c}\text { Share } \\
(\%)\end{array}$ & $\begin{array}{c}\text { Invested } \\
\text { amount } \\
\text { (million } \\
\text { USD) }\end{array}$ & $\begin{array}{c}\text { Share } \\
(\%)\end{array}$ & $\begin{array}{l}\text { Invested } \\
\text { amount } \\
\text { (million } \\
\text { USD) }\end{array}$ & $\begin{array}{c}\text { Share } \\
(\%)\end{array}$ & $\begin{array}{l}\text { Invested } \\
\text { amount } \\
\text { (million } \\
\text { USD) }\end{array}$ & $\begin{array}{c}\text { Share } \\
(\%)\end{array}$ & $\begin{array}{l}\text { Total } \\
\text { investment } \\
\text { (million } \\
\text { USD) }\end{array}$ & $\begin{array}{c}\text { Share } \\
(\%)\end{array}$ \\
\hline Total & 9,420 & 100.0 & 13,072 & 100.0 & 13,678 & 100.0 & 27,797 & 100.0 & 27,027 & 100.0 & 90,994 & $\overline{100.0}$ \\
\hline Agriculture, hunting, and forestry & 89 & 0.9 & 118 & 0.9 & 190 & 1.4 & 224 & 0.8 & 503 & 1.9 & 1,124 & 1.2 \\
\hline Fishing & 1 & 0.0 & 1 & 0.0 & 4 & 0.0 & 26 & 0.1 & 2 & 0.0 & 34 & 0.0 \\
\hline Mining and quarrying & 4,080 & 43.3 & 4,012 & 30.7 & 4,521 & 33.1 & 13,933 & 50.1 & 4,979 & 18.4 & 31,525 & 34.6 \\
\hline Fuel and energy resources & 3,984 & 42.3 & 3,913 & 29.9 & 4,313 & 31.5 & 13,670 & 49.2 & 4,645 & 17.2 & 30,525 & 33.5 \\
\hline Other mineral resources & 96 & 1.0 & 99 & 0.8 & 208 & 1.5 & 263 & 0.9 & 334 & 1.2 & 1,000 & 1.1 \\
\hline Manufacturing & 2,911 & 30.9 & 6,028 & 46.1 & 2,602 & 19.0 & 4,101 & 14.8 & 5,918 & 21.9 & 21,560 & 23.7 \\
\hline Food, beverages, and tobacco & 336 & 3.6 & 550 & 4.2 & 629 & 4.6 & 1,147 & 4.1 & 1,060 & 3.9 & 3,722 & 4.1 \\
\hline Textiles and clothing & 35 & 0.4 & 19 & 0.1 & 8 & 0.1 & 49 & 0.2 & 40 & 0.1 & 151 & 0.2 \\
\hline Leather, leather products, and shoes & 5 & 0.1 & 10 & 0.1 & 2 & 0.0 & 0 & 0.0 & 0 & 0.0 & 17 & 0.0 \\
\hline Wood processing and wood products & 326 & 3.5 & 329 & 2.5 & 296 & 2.2 & 234 & 0.8 & 566 & 2.1 & 1,751 & 1.9 \\
\hline Paper and pulp, printing, and publishing & 44 & 0.5 & 95 & 0.7 & 81 & 0.6 & 178 & 0.6 & 559 & 2.1 & 957 & 1.1 \\
\hline Coking coal and oil products & 5 & 0.1 & 3,555 & 27.2 & 7 & 0.1 & 21 & 0.1 & 15 & 0.1 & 3,603 & 4.0 \\
\hline Chemicals & 238 & 2.5 & 229 & 1.8 & 282 & 2.1 & 371 & 1.3 & 324 & 1.2 & 1,444 & 1.6 \\
\hline Rubber and plastic products & 75 & 0.8 & 154 & 1.2 & 208 & 1.5 & 273 & 1.0 & 296 & 1.1 & 1,006 & 1.1 \\
\hline Other non-ferrous metal and mineral products & 449 & 4.8 & 397 & 3.0 & 481 & 3.5 & 550 & 2.0 & 814 & 3.0 & 2,691 & 3.0 \\
\hline Metallurgy and metal processing & 1,142 & 12.1 & 173 & 1.3 & 221 & 1.6 & 565 & 2.0 & 782 & 2.9 & 2,883 & 3.2 \\
\hline Machinery and equipment & 60 & 0.6 & 166 & 1.3 & 127 & 0.9 & 77 & 0.3 & 197 & 0.7 & 627 & 0.7 \\
\hline Electrical, electronic, and optical products & 29 & 0.3 & 71 & 0.5 & 34 & 0.2 & 118 & 0.4 & 258 & 1.0 & 510 & 0.6 \\
\hline Transportation and transport equipment & 114 & 1.2 & 217 & 1.7 & 172 & 1.3 & 353 & 1.3 & 893 & 3.3 & 1,749 & 1.9 \\
\hline Electricity, gas, and water supply & 0 & 0.0 & 149 & 1.1 & 50 & 0.4 & 152 & 0.5 & 2,332 & 8.6 & 2,683 & 2.9 \\
\hline Construction & 87 & 0.9 & 117 & 0.9 & 271 & 2.0 & 891 & 3.2 & 958 & 3.5 & 2,324 & 2.6 \\
\hline Wholesale and retail trade ${ }^{\mathrm{a}}$ & 958 & 10.2 & 767 & 5.9 & 840 & 6.1 & 3,256 & 11.7 & 3,994 & 14.8 & 9,815 & 10.8 \\
\hline Hotels and restaurants & 20 & 0.2 & 21 & 0.2 & 21 & 0.2 & 49 & 0.2 & 72 & 0.3 & 183 & 0.2 \\
\hline Transport and communications & 196 & 2.1 & 245 & 1.9 & 379 & 2.8 & 591 & 2.1 & 1,282 & 4.7 & 2,693 & 3.0 \\
\hline Communications & 41 & 0.4 & 54 & 0.4 & 159 & 1.2 & 327 & 1.2 & 126 & 0.5 & 707 & 0.8 \\
\hline Financial intermediation & 356 & 3.8 & 589 & 4.5 & 1,502 & 11.0 & 1,123 & 4.0 & 1,713 & 6.3 & 5,283 & 5.8 \\
\hline Real estate, rental, and business activities & 650 & 6.9 & 930 & 7.1 & 3,210 & 23.5 & 3,273 & 11.8 & 5,043 & 18.7 & 13,106 & 14.4 \\
\hline Others & 72 & 0.8 & 95 & 0.7 & 88 & 0.6 & 178 & 0.6 & 231 & 0.9 & 664 & 0.7 \\
\hline
\end{tabular}

Note: ${ }^{\text {a }}$ Including repair of motor vehicles, motorcycles, and personal and household goods

Source: Russian Federal State Statistics Service (http://www.gks.ru/) 
Table 3. Regional breakdown of FDI in Russia, 2003-2011

(a) Cumulative FDI

\begin{tabular}{|c|c|c|}
\hline Rank & Entity & $\begin{array}{c}\text { FDI } \\
\text { (million } \\
\text { USD) }\end{array}$ \\
\hline 1 & Moscow & $48,648.2$ \\
\hline 2 & Sakhalin Region & $24,113.5$ \\
\hline 3 & Moscow Region & $15,211.3$ \\
\hline 4 & St. Petersburg & $6,036.0$ \\
\hline 5 & Omsk Region & $3,904.8$ \\
\hline 6 & Tyumen Region & $3,459.2$ \\
\hline 7 & Kaluga Region & $3,246.9$ \\
\hline 8 & Leningrad Region & $2,979.3$ \\
\hline 9 & Chelyabinsk Region & $2,567.3$ \\
\hline 10 & Arkhangelsk Region & $2,335.2$ \\
\hline 11 & Krasnodar Territory & $1,970.8$ \\
\hline 12 & Nizhny Novgorod Region & $1,942.6$ \\
\hline 13 & Tomsk Region & $1,854.5$ \\
\hline 14 & Republic of Tatarstan & $1,845.1$ \\
\hline 15 & Lipetsk Region & $1,582.8$ \\
\hline 16 & Republic of Komi & $1,439.9$ \\
\hline 17 & Vladimir Region & $1,407.4$ \\
\hline 18 & Amur Region & $1,348.0$ \\
\hline 19 & Novgorod Region & $1,214.2$ \\
\hline 20 & Sverdlovsk Region & $1,000.7$ \\
\hline 21 & Tula Region & 977.5 \\
\hline 22 & Rostov Region & 971.4 \\
\hline 23 & Orenburg Region & 949.8 \\
\hline 24 & Samara Region & 906.7 \\
\hline 25 & Primorsky Territory & 897.1 \\
\hline 26 & Irkutsk Region & 837.5 \\
\hline 27 & Kaliningrad Region & 687.9 \\
\hline 28 & Republic of Bashkortostan & 627.3 \\
\hline 29 & Kemerovo Region & 612.0 \\
\hline 30 & Republic of Khakasia & 603.9 \\
\hline 31 & Perm Territory & 498.4 \\
\hline 32 & Zabaikalsk Territory & 485.9 \\
\hline 33 & Kostroma Region & 481.0 \\
\hline 34 & Krasnoyarsk Territory & 425.7 \\
\hline 35 & Novosibirsk Region & 422.6 \\
\hline 36 & Tver Region & 420.1 \\
\hline 37 & Yaroslavl Region & 400.9 \\
\hline 38 & Saratov Region & 378.0 \\
\hline 39 & Khabarovsk Territory & 377.5 \\
\hline 40 & Ryazan Region & 377.2 \\
\hline 41 & Republic of Karelia & 349.7 \\
\hline 42 & Stavropol Territory & 327.2 \\
\hline 43 & Belgorod Region & 318.9 \\
\hline 44 & Magadan Region & 294.5 \\
\hline 45 & Voronezh Region & 279.7 \\
\hline 46 & Republic of Chuvashia & 265.6 \\
\hline 47 & Kirov Region & 261.4 \\
\hline 48 & Pskov Region & 233.0 \\
\hline 49 & Volgograd Region & 224.0 \\
\hline 50 & Kamchatka Territory & 203.8 \\
\hline 51 & Republic of Udmurtia & 190.7 \\
\hline 52 & Orel Region & 190.3 \\
\hline 53 & Republic of Sakha (Yakutia) & 185.6 \\
\hline 54 & Kursk Region & 165.1 \\
\hline 55 & Ivanovo Region & 162.5 \\
\hline 56 & Kurgan Region & 146.8 \\
\hline 57 & Altai Territory & 145.5 \\
\hline 58 & Ulyanovsk Region & 141.8 \\
\hline 59 & Astrakhan Region & 134.6 \\
\hline 60 & Vologda Region & 124.2 \\
\hline 61 & Murmansk Region & 123.2 \\
\hline 62 & Bryansk Region & 106.7 \\
\hline 63 & Republic of Mordovia & 106.1 \\
\hline 64 & Penza Region & 100.9 \\
\hline 65 & Smolensk Region & 84.3 \\
\hline 66 & Tambov Region & 75.6 \\
\hline 67 & Jewish Autonomous Area & 56.1 \\
\hline 68 & Republic of Tuva & 31.7 \\
\hline 69 & Republic of Buryatia & 15.8 \\
\hline 70 & Republic of Mari El & 7.0 \\
\hline 71 & Republic of Altai & 2.3 \\
\hline
\end{tabular}

(b) Cumulative FDI per capita

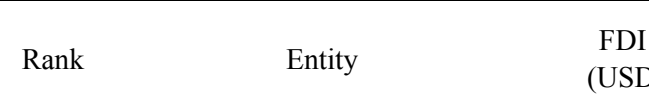

\begin{tabular}{lll}
\hline & Sakhalin Region & $48,714.2$
\end{tabular}

$4,189.1$

3 Kaluga Region 3,221.2

4 Moscow Region $2,113.0$

5 Omsk Region 1,977.1

6 Novgorod Region $\quad 1,927.3$

7 Arkhangelsk Region 1,925.1

8 Magadan Region $\quad 1,900.1$

9 Tomsk Region $\quad 1,752.9$

10 Leningrad Region $\quad 1,718.1$

11 Amur Region 1,641.9

12 Republic of Komi $\quad 1,617.8$

13 Lipetsk Region $\quad 1,357.5$

14 St. Petersburg 1,218.7

15 Republic of Khakasia $1,135.2$

16 Tyumen Region $\quad 999.8$

17 Vladimir Region $\quad 982.8$

18 Chelyabinsk Region $\quad 737.7$

19 Kostroma Region $\quad 726.5$

20 Kaliningrad Region 726.4

21 Kamchatka Territory 636.9

22 Tula Region 632.7

23 Nizhny Novgorod Region $\quad 589.2$

24 Republic of Karelia 546.5

25 Republic of Tatarstan 485.2

26 Orenburg Region 469.3

27 Primorsky Territory 459.8

28 Zabaikalsk Territory 441.7

29 Krasnodar Territory 373.0

30 Pskov Region $\quad 349.4$

31 Irkutsk Region 345.5

32 Ryazan Region $\quad 328.6$

33 Jewish Autonomous Area 320.8

34 Yaroslavl Region $\quad 315.4$

35 Tver Region 313.1

36 Samara Region 282.1

37 Khabarovsk Territory 281.3

38 Orel Region 243.7

39 Sverdlovsk Region 232.3

40 Rostov Region 228.0

41 Kemerovo Region 222.5

42 Republic of Chuvashia 213.0

43 Belgorod Region 207.6

44 Kirov Region 196.9

45 Republic of Sakha (Yakutia) 194.2

46 Perm Territory 189.4

47 Kurgan Region 163.9

48 Novosibirsk Region $\quad 157.3$

49 Murmansk Region 156.3

50 Republic of Bashkortostan $\quad 154.3$

51 Ivanovo Region 154.2

52 Saratov Region 150.7

53 Krasnoyarsk Territory 150.0

54 Kursk Region 147.1

55 Astrakhan Region $\quad 132.6$

56 Republic of Mordovia 128.6

57 Republic of Udmurtia 125.7

58 Voronezh Region $\quad 120.0$

59 Stavropol Territory $\quad 117.4$

60 Ulyanovsk Region 110.6

61 Vologda Region 103.7

62 Republic of Tuva 102.6

63 Volgograd Region $\quad 86.3$

64 Smolensk Region $\quad 85.9$

65 Bryansk Region $\quad 84.4$

66 Penza Region $\quad 73.3$

67 Tambov Region 69.9

68 Altai Territory 60.4

69 Republic of Buryatia 16.3

70 Republic of Altai 10.9

71 Republic of Mari El 10.1 
Table 4. List of studies that examine the impact of FDI on the Russian economy

\begin{tabular}{|c|c|c|c|c|c|}
\hline Author(s) & Estimation period & Objects of analysis & Estimation method ${ }^{\mathrm{a}}$ & Dependent variable & Estimation results regarding effects of $\mathrm{FDI}^{\mathrm{b}}$ \\
\hline $\begin{array}{l}\text { Brown and Earle (2000) } \\
\end{array}$ & 1992-1998 & 14,961 companies in Russia & OLS, RE & $\begin{array}{l}\text { Value of output the enterprise } \\
\text { produced in December } 1992 \\
\text { prices }\end{array}$ & $\begin{array}{l}\text { In survival regression> Dummy for the foreign-owned or foreign-domestic joint venture in } \\
1993(-) ;<\text { In basic regressions > Dummy for the foreign-owned or foreign-domestic joint } \\
\text { venture }(+) ; \text { <n ownership effects }>\text { Dummy for the foreign-owned or foreign-domestic } \\
\text { joint venture }(+)\end{array}$ \\
\hline Ponomareva (2000) & 1993-1997 & $\begin{array}{l}\text { Companies in Russia, with 5- } \\
1,000 \text { full-time employees } \\
\text { (four-digit classification } \\
\text { companies) }\end{array}$ & OLS, FE & Total output & 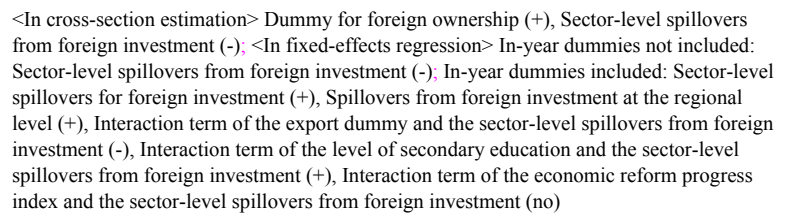 \\
\hline Bessonova et al. (2003) & $\begin{array}{l}\text { 1994-2000 (early period: } 1994 \\
\text {-1998, late period: } 1999-2000)\end{array}$ & $\begin{array}{l}\text { Russian companies in } 83 \\
\text { ) sectors }\end{array}$ & OLS, FE, RE & $\begin{array}{l}\text { Total factor productivity (TFP) } \\
\text { growth rate }\end{array}$ & 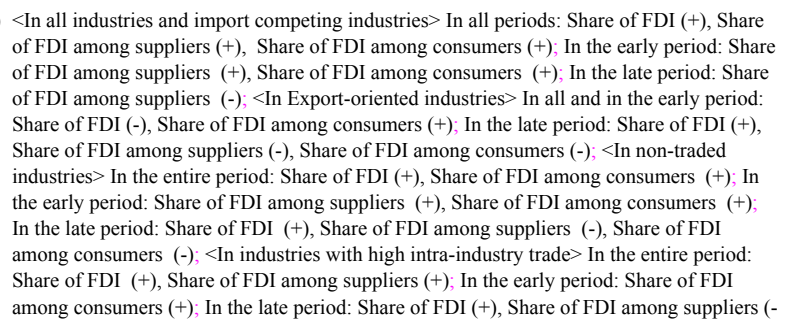 \\
\hline Yudaeva et al. (2003) & $\begin{array}{l}\text { (1) } 1996 \text { or } 1997 \text { (comparison } \\
\text { between foreign and domestic } \\
\text { companies); (2) 1993-1997 } \\
\text { (spillover effects from foreign } \\
\text { companies) }\end{array}$ & Russia & $\mathrm{FE}$ & Value added & Industry spillovers (+), Upstream spillovers (-), Downstream spillovers (-) \\
\hline Peter et al. (2004) & 1993-2000 & Russia and the Czech Republic & OLS, RE, FE, 2SLS-RE & $\begin{array}{l}\text { Productivity gap to foreign } \\
\text { frontier }\end{array}$ & $\begin{array}{l}<\text { In Russia> Spillover to domestic companies (early period (-) and thereafter }(-)) \text {, Spillover } \\
\text { to foreign companies (early period }(-) \text { and thereafter }(+))\end{array}$ \\
\hline Ahrend (2005) & 1990-1998 & $\begin{array}{l}77 \text { regions in Russia and the } \\
\text { European part of Russia }\end{array}$ & OLS, RE, 2SLS & $\begin{array}{l}\text { (1) Growth rate of per capita } \\
\text { GRP; (2) Growth rate of real } \\
\text { income per capita; (3) Growth } \\
\text { rate of industrial production }\end{array}$ & $\begin{array}{l}<\text { In all dependent variables }> \\
\text { All FDI variables (no), FDI per capita in the European part of Russia (+) }\end{array}$ \\
\hline Brock (2005) & $\begin{array}{l}\text { 1995-2000 (early period: } 1995 \\
\text {-1997, late period: } 1998 / 1999- \\
\text { 2000) }\end{array}$ & $\begin{array}{l}\text { Russian regions (plus } 40 \\
\text { subgroups) }\end{array}$ & OLS & Growth rate of GRP & $\begin{array}{l}\text { In all samples }>\text { In all periods: ratio of FDI in GRP (no), Change in cumulative FDI to } \\
\text { GRP (no); In the early period: Ratio of FDI in GRP (+); In the late period: Change in } \\
\text { cumulative FDI to GRP }(-) \text {; }<\text { subgroups by corruption> In all and the late period: Ratio } \\
\text { of FDI in GRP (no), Change in cumulative FDI to GRP (+), Interaction term of the number } \\
\text { of secondary school students per 10,000 residents and the change in the cumulative FDI to } \\
\text { GRP (-) }\end{array}$ \\
\hline Tytell and Yudaeva (2006) & $\mathrm{N} / \mathrm{A}$ & $\begin{array}{l}\text { Data of companies in Russia, } \\
\text { Ukraine, Poland, and Romania }\end{array}$ & OLS, GMM & $\begin{array}{l}\text { (1) Value added; (2) Total } \\
\text { factor productivity (TFP); (3) } \\
\text { Capital-labor ratio of domestic } \\
\text { firms }\end{array}$ & 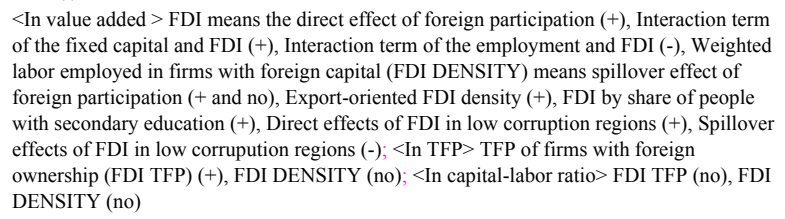 \\
\hline Ahrend (2008) & 1993-2004 & 77 regions in Russia & EBA & $\begin{array}{l}\text { (1) Pre-crisis growth: real GRP } \\
\text { growth 1995-1998; (2) Post- } \\
\text { crisis growth: real GRP growth } \\
\text { 1999-2004 }\end{array}$ & $<$ In pre- and post-crisis growth $>$ FDI per capita (1995) (no) \\
\hline Ledyaeva and Linden (2008) & $\begin{array}{l}\text { 1996-2005 (early period: } 1996- \\
\text { 1999, late period: 2000- } \\
\text { 2005) }\end{array}$ & -74 regions in Russia & OLS, LAD, FE, GMM & GRP growth rate & $\begin{array}{l}\text { <In all regions> In all periods: FDI (basically, no); In the early period: FDI (+) in OLS, FDI } \\
\text { (no) in GMM; < <n region groups by income> In high-income regions: FDI (-) in OLS; In } \\
\text { low-income regions: FDI (+) in GMM }\end{array}$ \\
\hline Dolgopyatova (2009) & 2009 & 64 regions ( 882 companies) & Logit, Probit & $\begin{array}{l}\text { Rate of decrease in } \\
\text { concentration of ownership }\end{array}$ & $\begin{array}{l}<\text { In strategic development }>\text { Emergence of strategic foreign partners }(+) ;<\text { In methods and } \\
\text { techniques of management }>\text { Standardization with foreign competitors }(+)\end{array}$ \\
\hline
\end{tabular}


Table 5. Definition, descriptive statistics, and a correlation matrix of the variables used in the empirical analysis

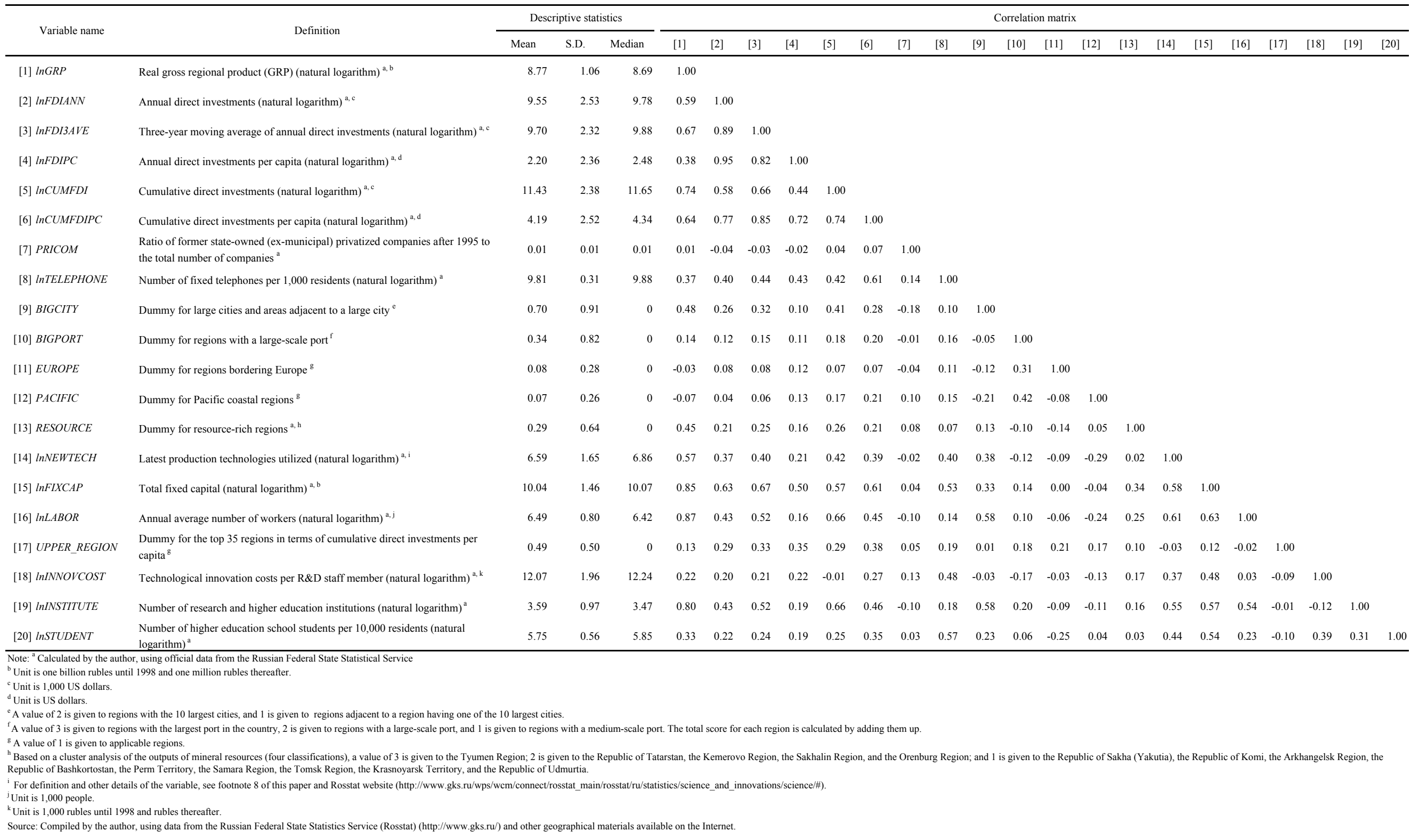


Table 6. Panel data estimation of the Russian regional production function: Baseline estimation ${ }^{\text {a }}$

\begin{tabular}{|c|c|c|c|c|c|c|c|c|c|c|}
\hline \multirow{4}{*}{$\begin{array}{l}\text { Estimation period } \\
\text { Target regions } \\
\text { Estimator }{ }^{\mathrm{b}} \\
\text { Model }\end{array}$} & \multicolumn{10}{|c|}{ 1996-2011 } \\
\hline & \multicolumn{10}{|c|}{ All 71 regions } \\
\hline & \multicolumn{5}{|c|}{$\mathrm{RE}$} & \multicolumn{5}{|c|}{ system GMM } \\
\hline & [1] & {$[2]$} & {$[3]$} & [4] & [5] & {$[6]$} & {$[7]$} & {$[8]$} & [9] & {$[10]$} \\
\hline $\begin{array}{l}\text { Lagged endogenous variable } \\
\ln G R P\end{array}$ & & & & & & $\begin{array}{l}0.1536^{* * *} \\
(0.033)\end{array}$ & $\begin{array}{l}0.2227^{* * *} \\
(0.078)\end{array}$ & $\begin{array}{l}0.1511^{* * *} \\
(0.034)\end{array}$ & $\begin{array}{l}0.2067^{* * *} \\
(0.071)\end{array}$ & $\begin{array}{l}0.1703^{* * *} \\
(0.045)\end{array}$ \\
\hline $\begin{array}{c}\text { FDI variables }{ }^{c} \\
\ln F D I A N N\end{array}$ & $\begin{array}{l}0.0037 \\
(0.002)\end{array}$ & & & & & $\begin{array}{l}0.0119^{* * *} \\
(0.004)\end{array}$ & & & & \\
\hline $\operatorname{lnFDI3AVE}$ & & $\begin{array}{l}0.0094^{*} \\
(0.005)\end{array}$ & & & & & $\begin{array}{r}0.0083 \\
(0.007)\end{array}$ & & & \\
\hline $\ln F D I P C$ & & & $\begin{array}{l}0.0027 \\
(0.002)\end{array}$ & & & & & $\begin{array}{l}0.0111^{* * *} \\
(0.004)\end{array}$ & & \\
\hline $\ln C U M F D I$ & & & & $\begin{array}{l}0.0809^{* * * *} \\
(0.024)\end{array}$ & & & & & $\begin{array}{l}0.14011^{*} \\
(0.074)\end{array}$ & \\
\hline $\ln C U M F D I P C$ & & & & & $\begin{array}{l}0.0369^{* * *} \\
(0.010)\end{array}$ & & & & & $\begin{array}{l}0.0591^{* *} \\
(0.025)\end{array}$ \\
\hline \multicolumn{11}{|l|}{ Control variables } \\
\hline PRICOM & $\begin{array}{r}3.0711 \\
(2.965)\end{array}$ & $\begin{array}{l}3.1517 \\
(2.933)\end{array}$ & $\begin{array}{l}3.1795 \\
(2.973)\end{array}$ & $\begin{array}{r}1.8816 \\
(2.845)\end{array}$ & $\begin{array}{r}3.1719 \\
(2.854)\end{array}$ & $\begin{array}{r}2.2107 \\
(4.496)\end{array}$ & $\begin{array}{r}1.6606 \\
(4.066)\end{array}$ & $\begin{array}{l}1.5021 \\
(4.502)\end{array}$ & $\begin{array}{r}2.4509 \\
(3.943)\end{array}$ & $\begin{array}{r}3.4102 \\
(4.049)\end{array}$ \\
\hline InTELEPHONE & $\begin{array}{l}0.1282 \\
(0.091)\end{array}$ & $\begin{array}{l}0.1251 \\
(0.091)\end{array}$ & $\begin{array}{r}0.1287 \\
(0.091)\end{array}$ & $\begin{array}{l}0.0845 \\
(0.087)\end{array}$ & $\begin{array}{l}0.0921 \\
(0.088)\end{array}$ & $\begin{array}{l}0.1954^{*} \\
(0.119)\end{array}$ & $\begin{array}{l}0.0404 \\
(0.104)\end{array}$ & $\begin{array}{l}0.1800 \\
(0.117)\end{array}$ & $\begin{array}{c}0.0632 \\
(0.110)\end{array}$ & $\begin{array}{r}0.0696 \\
(0.102)\end{array}$ \\
\hline BIGCITY & $\begin{array}{r}-0.0153 \\
(0.045)\end{array}$ & $\begin{array}{r}-0.0166 \\
(0.045)\end{array}$ & $\begin{array}{r}-0.0149 \\
(0.045)\end{array}$ & $\begin{array}{r}-0.0410 \\
(0.040)\end{array}$ & $\begin{array}{r}-0.0260 \\
(0.044)\end{array}$ & & & & & \\
\hline BIGPORT & $\begin{array}{c}0.0012 \\
(0.050)\end{array}$ & $\begin{array}{l}0.0027 \\
(0.050)\end{array}$ & $\begin{array}{l}0.0011 \\
(0.050)\end{array}$ & $\begin{array}{c}0.0240 \\
(0.043)\end{array}$ & $\begin{array}{c}0.0045 \\
(0.049)\end{array}$ & & & & & \\
\hline EUROPE & $\begin{array}{l}0.1364 \text { * } \\
(0.077)\end{array}$ & $\begin{array}{l}0.1275 \\
(0.077)\end{array}$ & $\begin{array}{l}0.1374 \text { * } \\
(0.077)\end{array}$ & $\begin{array}{l}0.0060 \\
(0.082)\end{array}$ & $\begin{array}{l}0.1011 \\
(0.086)\end{array}$ & & & & & \\
\hline PACIFIC & $\begin{array}{l}0.3272^{* *} \\
(0.151)\end{array}$ & $\begin{array}{l}0.3122^{* *} \\
(0.152)\end{array}$ & $\begin{array}{l}0.3283^{* *} \\
(0.152)\end{array}$ & $\begin{array}{l}0.0302 \\
(0.150)\end{array}$ & $\begin{array}{l}0.2222 \\
(0.165)\end{array}$ & & & & & \\
\hline RESOURCE & $\begin{array}{l}0.2780^{* * *} \\
(0.065)\end{array}$ & $\begin{array}{l}0.2771^{* * *} \\
(0.065)\end{array}$ & $\begin{array}{l}0.2780^{* * *} \\
(0.065)\end{array}$ & $\begin{array}{l}0.25333^{* * *} \\
(0.055)\end{array}$ & $\begin{array}{l}0.27622^{* * *} \\
(0.067)\end{array}$ & & & & & \\
\hline $\operatorname{lnNEWTECH}$ & $\begin{array}{r}0.0091 \\
(0.020)\end{array}$ & $\begin{array}{l}0.0097 \\
(0.020)\end{array}$ & $\begin{array}{l}0.0093 \\
(0.020)\end{array}$ & $\begin{array}{r}0.0047 \\
(0.019)\end{array}$ & $\begin{array}{c}0.0042 \\
(0.018)\end{array}$ & $\begin{array}{c}0.0228 \\
(0.020)\end{array}$ & $\begin{array}{r}0.0310 \\
(0.024)\end{array}$ & $\begin{array}{l}0.0245 \\
(0.019)\end{array}$ & $\begin{array}{r}0.0164 \\
(0.020)\end{array}$ & $\begin{array}{r}0.0263 \\
(0.020)\end{array}$ \\
\hline $\ln F I X C A P$ & $\begin{array}{l}0.26655^{* * * *} \\
(0.020)\end{array}$ & $\begin{array}{l}0.2636 \\
(0.020)\end{array}$ & $\begin{array}{l}0.2672^{* * * *} \\
(0.020)\end{array}$ & $\begin{array}{l}0.2746^{* * * *} \\
(0.018)\end{array}$ & $\begin{array}{l}0.2432^{* * *} \\
(0.022)\end{array}$ & $\begin{array}{l}0.2088^{* * *} \\
(0.019)\end{array}$ & $\begin{array}{l}0.2080 \\
(0.026)\end{array}$ & $\begin{array}{l}0.2143^{* * *} \\
(0.020)\end{array}$ & $\begin{array}{l}0.20555^{* * *} \\
(0.024)\end{array}$ & $\begin{array}{l}0.1837^{* * *} \\
(0.022)\end{array}$ \\
\hline $\ln \angle A B O R$ & $\begin{array}{l}0.7770^{* * *} \\
(0.060)\end{array}$ & $\begin{array}{l}0.7674^{* * *} \\
(0.058)\end{array}$ & $\begin{array}{l}0.7794^{* * *} \\
(0.060)\end{array}$ & $\begin{array}{l}0.62600^{* * *} \\
(0.067)\end{array}$ & $\begin{array}{l}0.76722^{* * *} \\
(0.056)\end{array}$ & $\begin{array}{l}1.0401^{* * *} \\
(0.356)\end{array}$ & $\begin{array}{l}0.7279^{* *} \\
(0.370)\end{array}$ & $\begin{array}{l}0.9506^{* *} \\
(0.378)\end{array}$ & $\begin{array}{l}1.1175^{* * *} \\
(0.291)\end{array}$ & $\begin{array}{l}1.57011^{* * *} \\
(0.329)\end{array}$ \\
\hline Constant term & $\begin{array}{r}-0.4421 \\
(0.866)\end{array}$ & $\begin{array}{r}-0.3760 \\
(0.855)\end{array}$ & $\begin{array}{l}-0.4427 \\
(0.862)\end{array}$ & $\begin{array}{l}0.0843 \\
(0.846)\end{array}$ & $\begin{array}{r}0.1402 \\
(0.829)\end{array}$ & $\begin{array}{l}-3.6520^{*} \\
(2.115)\end{array}$ & $\begin{array}{r}-0.6253 \\
(2.306)\end{array}$ & $\begin{array}{r}-2.8614 \\
(2.295)\end{array}$ & $\begin{array}{l}-4.0859^{* *} \\
(1.873)\end{array}$ & $\begin{array}{l}-5.84311^{* * *} \\
(2.098)\end{array}$ \\
\hline Individual effects of regions & yes & yes & yes & yes & yes & yes & yes & yes & yes & yes \\
\hline Time fixed effects & yes & yes & yes & yes & yes & yes & yes & yes & yes & yes \\
\hline$N$ & 920 & 937 & 921 & 944 & 944 & 817 & 792 & 817 & 872 & 872 \\
\hline$R^{2}$ & 0.91 & 0.91 & 0.91 & 0.92 & 0.91 & na & na & na & na & na \\
\hline Breush-Pagan test $\left(\chi^{2}\right)^{d}$ & $2123.62^{* * * *}$ & $2210.80^{* * *}$ & $2131.3^{* * * *}$ & $1998.94^{* * * *}$ & $2277.74^{* * * *}$ & na & na & na & na & na \\
\hline Sargan test $\left(\chi^{2}\right)^{e}$ & na & na & na & na & na & 32.37 & 23.47 & 33.25 & 28.80 & 31.67 \\
\hline Arellano-Bond test $(z)^{\mathrm{f}}$ & na & na & na & na & na & -0.21 & 1.48 & -0.32 & 0.43 & -0.005 \\
\hline Wald test $\left(\chi^{2}\right)^{g}$ & $1836.88^{* * *}$ & $1847.51^{* * *}$ & $1827.18^{* * *}$ & $1985.63^{* * * *}$ & $1899.67^{* * * *}$ & $1940.98^{* * * *}$ & $2288.36^{* * * *}$ & $1912.69^{* * *}$ & $2186.42^{* * *}$ & $1845.97^{* * *}$ \\
\hline \multicolumn{11}{|c|}{ Note: ${ }^{a}$ The dependent variables of all models are the natural logarithm of the real gross regional product $(\ln G R P)$. Figures in parentheses beneath regression coefficients are robust standard errors. $* * *, * *$, and $*$ denote statistical significance at } \\
\hline 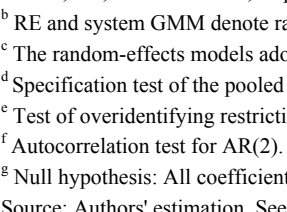 & $\begin{array}{l}\text { estimator and sy } \\
\text { gged FDI variab } \\
r \text { and the randon } \\
\text { nates with norm } \\
\text { is: No autocorre }\end{array}$ & $\begin{array}{l}\mathrm{n} \text { generalized } \mathrm{m} \\
\text { while the syster } \\
\text { fects estimator. } \\
\text { tandard errors. } \\
\text { n. }\end{array}$ & $\begin{array}{l}\text { d-of-moments ( } \\
\text { MM dynamic m } \\
\text { hypothesis: Va } \\
\text { hypothesis: Ove }\end{array}$ & $\begin{array}{l}\text { M) estimator, re } \\
\text { s endogenize no } \\
\text { e of individual } \\
\text { ntifying restrict }\end{array}$ & $\begin{array}{l}\text { tively. } \\
\text { gged FDI variat } \\
\text { ts is zero. } \\
\text { are valid. }\end{array}$ & hing a two- & tructure. & & & \\
\hline
\end{tabular}


Table 7. Panel data estimation of the relationship between the size of FDI and regional total factor productivity ${ }^{\text {a }}$

(a) Subsample estimation using observations of the higher regions in terms of cumulative FDI per capita

\begin{tabular}{|c|c|c|c|c|c|c|c|c|c|c|}
\hline \multirow{4}{*}{$\begin{array}{l}\text { Estimation period } \\
\text { Target regions } \\
\text { Estimator }^{\mathrm{b}} \\
\text { Model }\end{array}$} & \multicolumn{10}{|c|}{ 1996-2011 } \\
\hline & \multicolumn{10}{|c|}{ The top 35 regions in cumulative FDI per capita from 2003-2011 } \\
\hline & \multicolumn{5}{|c|}{ RE } & \multicolumn{5}{|c|}{ system GMM } \\
\hline & [1] & [2] & [3] & [4] & [5] & [6] & [7] & [8] & [9] & {$[10]$} \\
\hline FDI variables $^{c}$ & & & & & & & & & & \\
\hline $\ln F D I 3 A V E$ & & $\begin{array}{r}0.0087 \\
(0.006)\end{array}$ & & & & & $\begin{array}{c}0.0144 \\
(0.011)\end{array}$ & & & \\
\hline $\ln F D I P C$ & & & $\begin{array}{l}0.0035 \\
(0.004)\end{array}$ & & & & & $\begin{array}{l}0.01255^{*} \\
(0.008)\end{array}$ & & \\
\hline $\ln C U M F D I$ & & & & $\begin{array}{l}0.1069^{* * *} \\
(0.035)\end{array}$ & & & & & $\begin{array}{l}0.2502 \\
(0.059)\end{array}$ & \\
\hline $\ln C U M F D I P C$ & & & & & $\begin{array}{l}0.0265 \\
(0.014)\end{array}$ & & & & & $\begin{array}{l}0.0439 \\
(0.039)\end{array}$ \\
\hline $\bar{N}$ & 460 & 461 & 460 & 461 & 461 & 419 & 392 & 419 & 425 & 425 \\
\hline Wald test $\left(\chi^{2}\right)^{\mathrm{d}}$ & $1430.71^{* * *}$ & $1447.67^{* * *}$ & $1449.97^{* * *}$ & $2084.45^{* * *}$ & $1350.63^{* * *}$ & $968.45^{* * *}$ & $1714.93^{* * *}$ & $922.57^{* * *}$ & $1515.21^{* * *}$ & $1067.52^{* * *}$ \\
\hline
\end{tabular}

(b) Estimation with the dummy for the top 35 regions in terms of cumulative FDI per capita from 1996-2011 and its interaction term with an FDI variable

\begin{tabular}{|c|c|c|c|c|c|c|c|c|c|c|}
\hline \multirow{3}{*}{$\begin{array}{l}\text { Estimation period } \\
\text { Target regions } \\
\text { Estimator }^{\mathrm{b}} \\
\end{array}$} & \multicolumn{10}{|c|}{$1996-2011$} \\
\hline & \multicolumn{10}{|c|}{ All 71 regions } \\
\hline & & & RE & & & & & ystem GMM & & \\
\hline Model & [11] & {$[12]$} & [13] & [14] & {$[15]$} & {$[16]$} & {$[17]$} & {$[18]$} & [19] & {$[20]$} \\
\hline \multicolumn{11}{|l|}{ FDI variables $^{c}$} \\
\hline $\operatorname{lnFDI3AVE}$ & & $\begin{array}{r}0.0009 \\
(0.008)\end{array}$ & & & & & $\begin{array}{r}-0.0015 \\
(0.005)\end{array}$ & & & \\
\hline $\operatorname{lnFDIPC}$ & & & $\begin{array}{r}-0.0038 \\
(0.003)\end{array}$ & & & & & $\begin{array}{r}0.0068 \\
(0.005)\end{array}$ & & \\
\hline $\ln C U M F D I P C$ & & & & & $\begin{array}{l}0.0253^{* *} \\
(0.013)\end{array}$ & & & & & $\begin{array}{l}0.05500^{* *} \\
(0.027)\end{array}$ \\
\hline \multicolumn{11}{|c|}{ Dummy for the top 35 regions in terms of cumulative FDI per capita } \\
\hline UPPER_REGION & $\begin{array}{r}-0.0007 \\
(0.084)\end{array}$ & $\begin{array}{r}-0.0220 \\
(0.115)\end{array}$ & $\begin{array}{r}0.0953 \\
(0.065)\end{array}$ & $\begin{array}{c}-0.6972 \\
(0.381)\end{array}$ & $\begin{array}{r}0.0170 \\
(0.088)\end{array}$ & & & & & \\
\hline \multicolumn{11}{|c|}{$\begin{array}{l}\text { Interaction term of FDI variable and dummy for the top } 35 \text { regions in } \\
\text { terms of cumulative FDI per capita }{ }^{c}\end{array}$} \\
\hline$F D I \times U P P E R \_R E G I O N$ & $\begin{array}{l}0.0127^{* *} \\
(0.005)\end{array}$ & $\begin{array}{r}0.0139 \\
(0.009)\end{array}$ & $\begin{array}{l}0.0118^{* *} \\
(0.005)\end{array}$ & $\begin{array}{l}0.0649^{* *} \\
(0.032)\end{array}$ & $\begin{array}{r}0.0145 \\
(0.013)\end{array}$ & $\begin{array}{r}0.0132 \\
(0.009)\end{array}$ & $\begin{array}{l}0.0201 \\
(0.012)\end{array}$ & $\begin{array}{r}0.0094 \\
(0.007)\end{array}$ & $\begin{array}{l}0.2612^{* * *} \\
(0.088)\end{array}$ & $\begin{array}{r}0.0023 \\
(0.037)\end{array}$ \\
\hline Wald test $\left(\chi^{2}\right)^{\mathrm{d}}$ & $2020.94^{* * *}$ & $2040.02^{* * *}$ & $2004.76^{* * *}$ & $2367.15^{* * *}$ & $2103.75^{* * *}$ & $1905.37^{* * *}$ & $2274.63^{* * *}$ & $1975.66^{* * *}$ & $2903.37^{* * *}$ & $1939.23^{* * *}$ \\
\hline
\end{tabular}




Estimation period
Target regions
Estimator $^{\mathrm{b}}$

Model

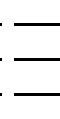

FDI variables ${ }^{\mathrm{C}}$

$\operatorname{lnFDIANN}$

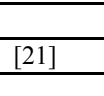

RE

All 71 regions

$-0.0395^{* * *}$

$\ln F D I 3 A V E$

$(0.012)$

[23]

$[24]$

$[25]$

$[26]$

system GMM

[29]

$-0.0219^{*}$

$(0.012)$

$\operatorname{lnFDIPC}$

$-0.0691^{* * *}$

$-0.0186$

$(0.011)$

$-0.0010$

$(0.003)$

$\ln C U M F D I$

$\ln C U M F D I P C$

$-0.1934^{* * *}$

-0.1934
$(0.073)$

0.0058
$(0.004)$

Squared term of FDI variable

$-0.0249^{*}$

$-0.1648$

\begin{tabular}{|c|c|c|c|c|c|c|c|c|c|c|}
\hline th & $\begin{array}{l}0.0028 \\
(0.001) \\
\end{array}$ & $\begin{array}{r}0.0048 \\
(0.001) \\
\end{array}$ & $\begin{array}{r}0.0029 \\
(0.001) \\
\end{array}$ & $\begin{array}{l}0.0 .140 \\
(0.003) \\
\end{array}$ & $\begin{array}{l}0.0088 \\
(0.001) \\
\end{array}$ & $\begin{array}{l}0.0000 \\
(0.001) \\
\end{array}$ & $\begin{array}{r}0.0016 \\
(0.001) \\
\end{array}$ & $\begin{array}{l}0.0004 \\
(0.001) \\
\end{array}$ & $\begin{array}{r}0.0225 \\
(0.009) \\
\end{array}$ & $\begin{array}{l}0.0053 \\
(0.003) \\
\end{array}$ \\
\hline $\bar{N}$ & 920 & 937 & 921 & 944 & 944 & 817 & 792 & 817 & 872 & 872 \\
\hline Wald test $\left(\chi^{2}\right)^{\mathrm{d}}$ & $1997.19^{* * *}$ & $2107.34^{* * *}$ & $1925.93^{* * *}$ & $2994.72^{* * *}$ & $2271.87^{* * *}$ & $2196.06^{* * *}$ & $2792.51^{* * *}$ & $2011.40^{* * *}$ & $3276.12^{* * *}$ & $2170.30^{* * *}$ \\
\hline
\end{tabular}

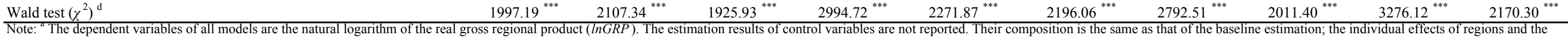

time fixed effects are also controlled. Figures in parentheses beneath regression coefficients are robust standard errors. ***,**, and * denote statistical significance at the $1 \%, 5 \%$, and $10 \%$ levels, respectively

${ }^{\mathrm{b}} \mathrm{RE}$ and system GMM denote random-effects estimator and system generalized method-of-moments (GMM) estimator, respectively.

${ }^{\mathrm{c}}$ The random-effects models adopt one-year lagged FDI variables and their interaction and squared terms, while the system GMM dynamic models endogenize non-lagged FDI variables and their interaction and squared terms, assuming their two-year lag structure.

${ }^{d}$ Null hypothesis: All coefficients are zero.

Source: Authors' estimation. See Table 5 for the definitions and descriptive statistics of the variables used in the estimation 
Figure 1. Relationship between regional R\&D potential and FDI in Russia, 1996-2011

(a) Horizontal axis: the natural logarithm of the number of the latest production technologies utilized (InNEWTECH)

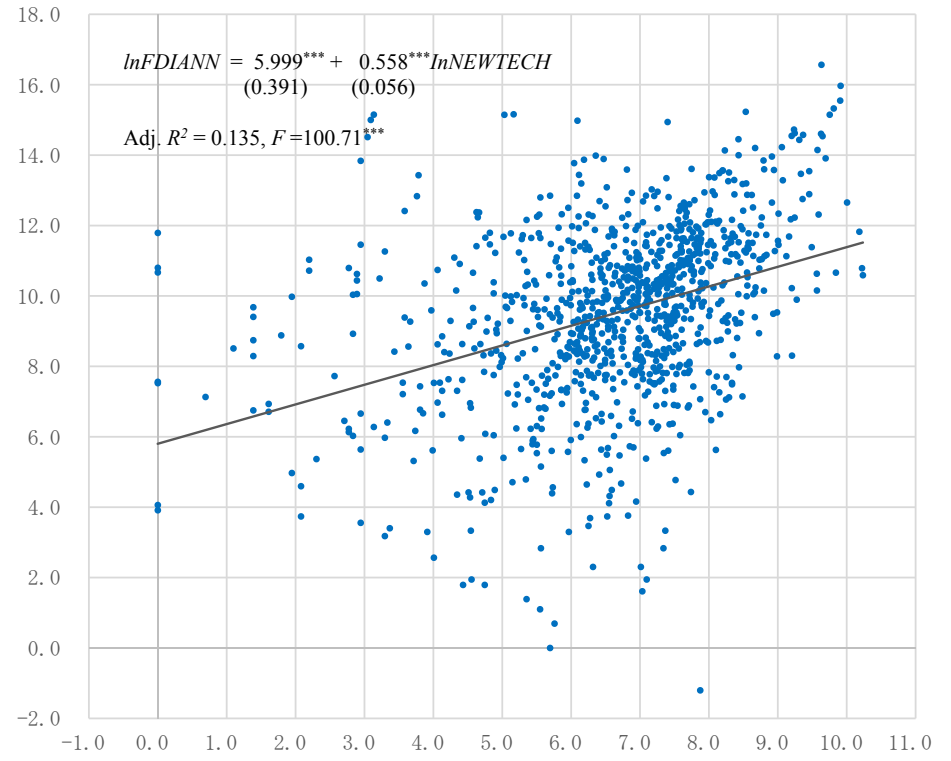

(c) Horizontal axis: the natural logarithm of the total number of research and higher education institutions (InINSTITUTE)

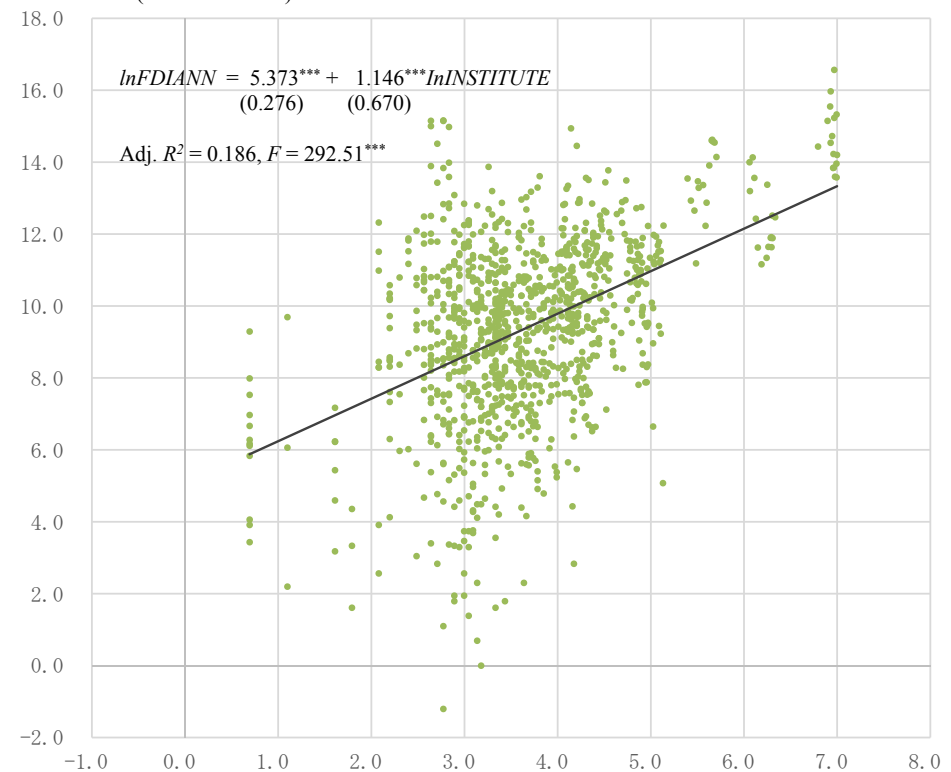

(b) Horizontal axis: the natural logarithm of technological innovation costs per R\&D staff member (InINNOVCOST)

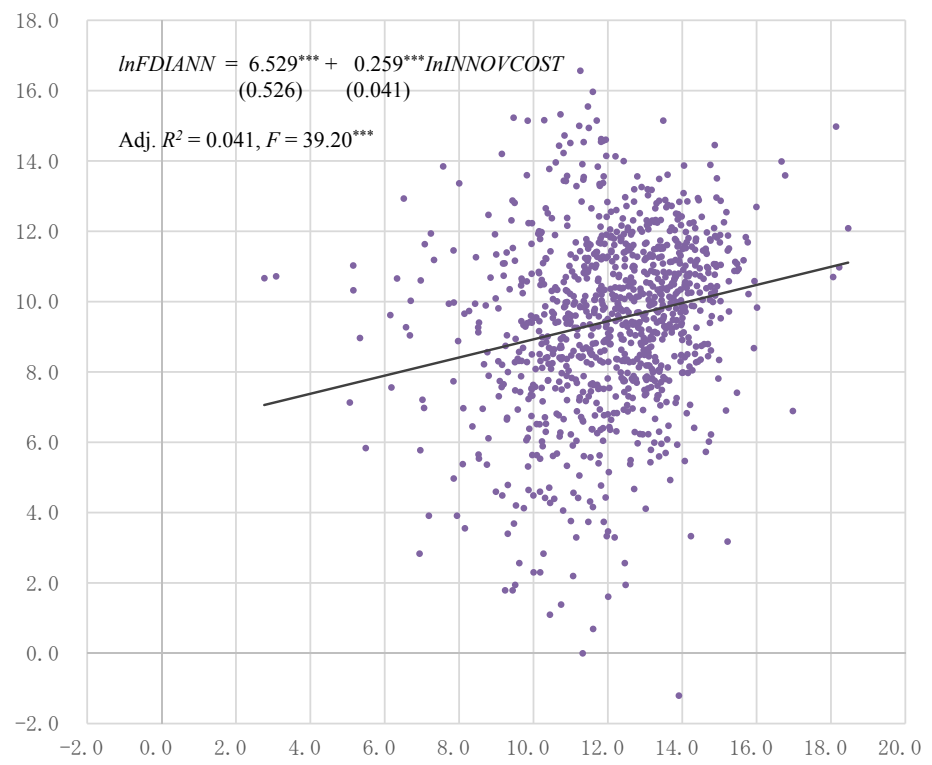

(d) Horizontal axis: the natural logarithm of the number of higher education school students per 10,000 residents (InSTUDENT)

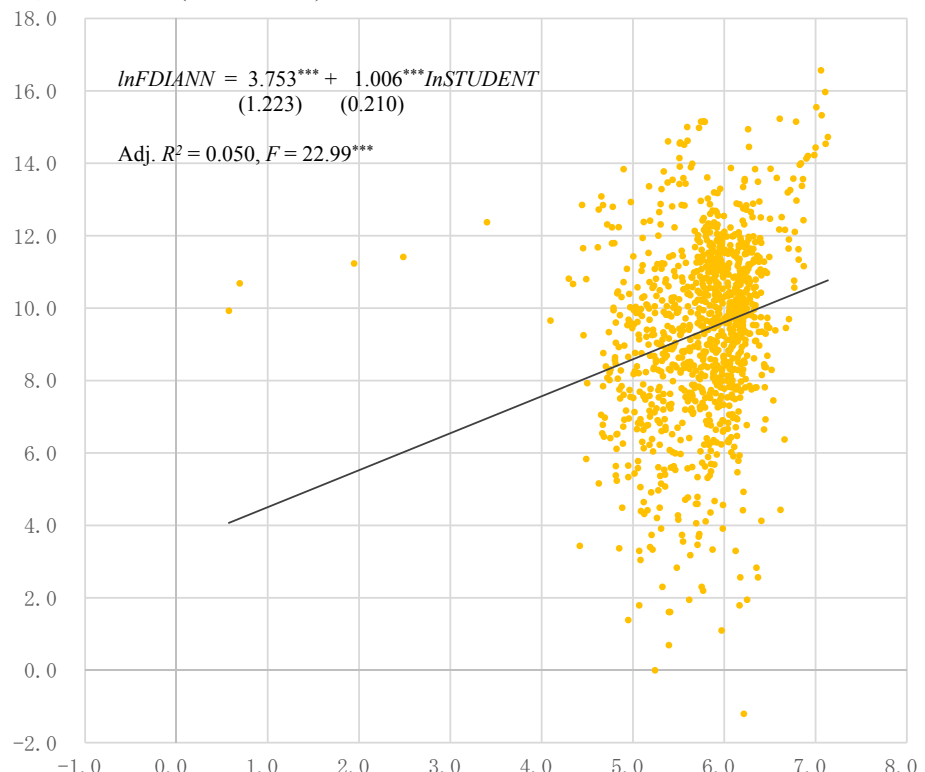

Note: The vertical axis is the zero. ${ }^{* * *}$ denotes statistical significance at the $1 \%$ level.

Source: Authors' illustration. See Table 5 for the definitions and descriptive statistics of the variables. 
Table 8. Panel data estimation of the synergy effect of FDI and regional R\&D potential ${ }^{\text {a }}$

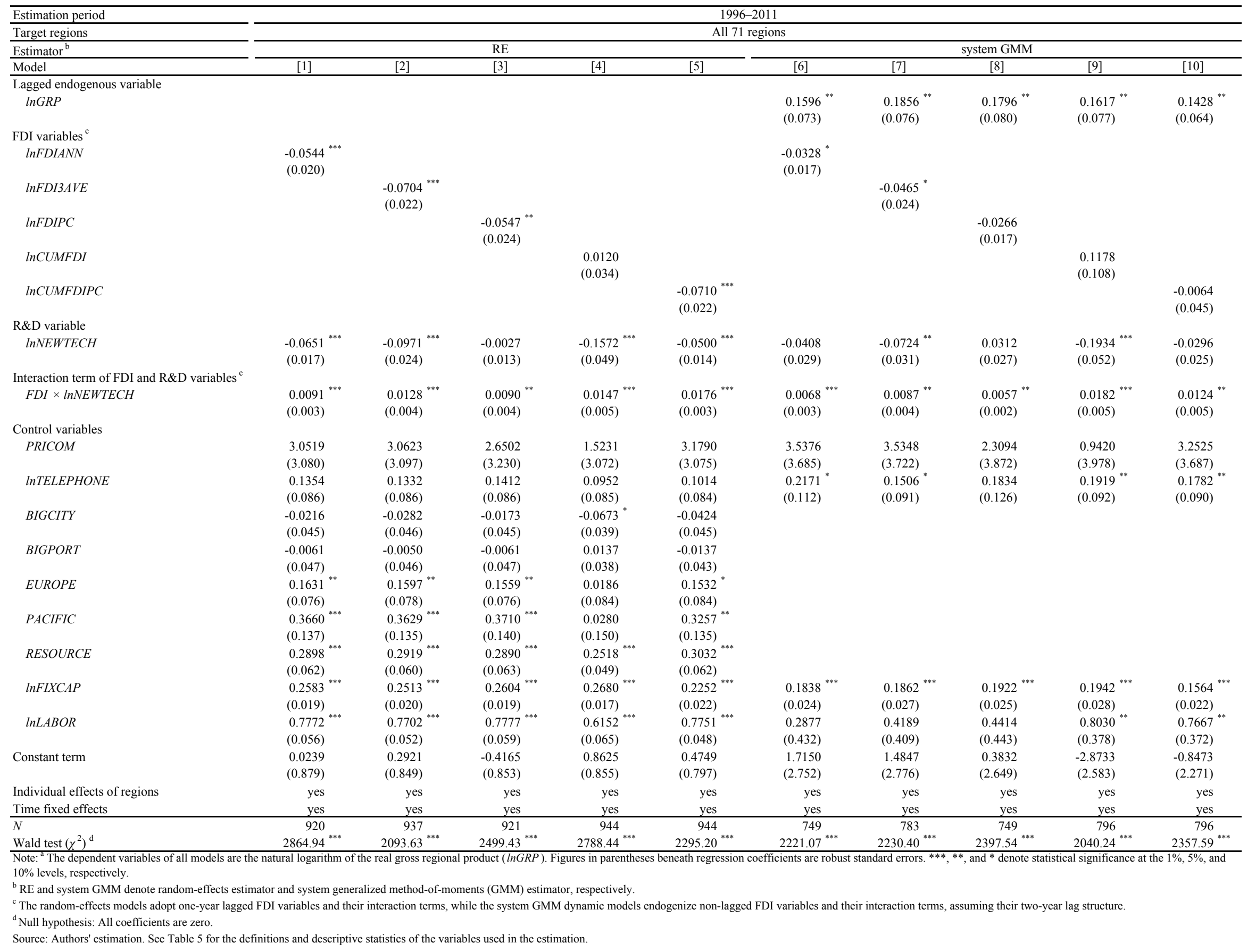


Table 9. The effect of FDI on regional total factor productivity in 2011: Predicted

\begin{tabular}{|c|c|c|c|c|c|c|}
\hline \multirow[b]{2}{*}{$\begin{array}{c}\text { Ranking of } \\
\text { total FDI } \\
\text { effect }\end{array}$} & \multirow[b]{2}{*}{ Entity $^{a}$} & \multirow{2}{*}{$\begin{array}{l}\text { Cumulative } \\
\text { direct } \\
\text { investments } \\
\text { per capita in } \\
2011 \text { (US } \\
\text { dollars) }\end{array}$} & \multirow{2}{*}{$\begin{array}{c}\text { The number of } \\
\text { latest } \\
\text { production } \\
\text { technologies } \\
\text { utilized in } \\
2011\end{array}$} & \multicolumn{3}{|c|}{$\begin{array}{l}\text { The effect of FDI on regional total factor } \\
\text { productivity }{ }^{b}\end{array}$} \\
\hline & & & & $\begin{array}{l}\text { Direct effect } \\
\text { of FDI } \\
\text { (a) }\end{array}$ & $\begin{array}{l}\text { Synergistic } \\
\text { effect between } \\
\text { FDI and R\&D } \\
\text { potential } \\
\text { (b) }\end{array}$ & $\begin{array}{c}\text { Total FDI } \\
\text { effect } \\
(a+b)\end{array}$ \\
\hline 1 & Moscow & 47,639 & 17,205 & -0.764 & 1.851 & 1.086 \\
\hline 2 & Moscow Region & 15,469 & 15,159 & -0.685 & 1.636 & 0.951 \\
\hline 3 & St. Petersburg & 10,976 & 5,122 & -0.660 & 1.400 & 0.740 \\
\hline 4 & Nizhny Novgorod Region & 1,738 & 12,781 & -0.529 & 1.243 & 0.713 \\
\hline 5 & Sverdlovsk Region & 1,746 & 10,337 & -0.530 & 1.216 & 0.686 \\
\hline 6 & Republic of Tatarstan & 2,451 & 4,847 & -0.554 & 1.167 & 0.613 \\
\hline 7 & Samara Region & 1,170 & 6,870 & -0.501 & 1.100 & 0.598 \\
\hline 8 & Sakhalin Region & 172,322 & 906 & -0.856 & 1.446 & 0.591 \\
\hline 9 & Tyumen Region & 1,015 & 6,675 & -0.491 & 1.074 & 0.583 \\
\hline 10 & Krasnodar Territory & 5,592 & 2,128 & -0.612 & 1.165 & 0.553 \\
\hline 11 & Chelyabinsk Region & 817 & 5,801 & -0.476 & 1.024 & 0.548 \\
\hline 12 & Kaluga Region & 3,366 & 2,316 & -0.576 & 1.109 & 0.532 \\
\hline 13 & Tula Region & 834 & 4,898 & -0.477 & 1.007 & 0.530 \\
\hline 14 & Vladimir Region & 1,225 & 3,239 & -0.505 & 1.013 & 0.508 \\
\hline 15 & Omsk Region & 1,599 & 2,632 & -0.524 & 1.024 & 0.500 \\
\hline 16 & Perm Territory & 576 & 4,510 & -0.451 & 0.942 & 0.491 \\
\hline 17 & Lipetsk Region & 1,449 & 2,265 & -0.517 & 0.991 & 0.474 \\
\hline 18 & Novgorod Region & 1,709 & 1,944 & -0.528 & 0.993 & 0.465 \\
\hline 19 & Arkhangelsk Region & 2,772 & 1,414 & -0.563 & 1.013 & 0.451 \\
\hline 20 & Leningrad Region & 4,229 & 1,195 & -0.593 & 1.042 & 0.450 \\
\hline 21 & Tomsk Region & 1,043 & 1,902 & -0.493 & 0.925 & 0.431 \\
\hline 22 & Republic of Bashkortostan & 163 & 6,207 & -0.361 & 0.784 & 0.422 \\
\hline 23 & Primorsky Territory & 1,506 & 1,404 & -0.519 & 0.934 & 0.415 \\
\hline 24 & Rostov Region & 439 & 2,670 & -0.432 & 0.846 & 0.414 \\
\hline 25 & Tver Region & 420 & 2,394 & -0.429 & 0.828 & 0.399 \\
\hline 26 & Novosibirsk Region & 389 & 2,457 & -0.423 & 0.820 & 0.397 \\
\hline 27 & Volgograd Region & 528 & 1,989 & -0.445 & 0.839 & 0.394 \\
\hline 28 & Yaroslavl Region & 285 & 2,642 & -0.401 & 0.785 & 0.383 \\
\hline 29 & Khabarovsk Territory & 292 & 2,559 & -0.403 & 0.785 & 0.382 \\
\hline 30 & Saratov Region & 143 & 4,359 & -0.352 & 0.732 & 0.380 \\
\hline 31 & Krasnoyarsk Territory & 349 & 1,979 & -0.415 & 0.783 & 0.367 \\
\hline 32 & Altai Territory & 494 & 1,511 & -0.440 & 0.800 & 0.360 \\
\hline 33 & Republic of Mordovia & 192 & 2,626 & -0.373 & 0.729 & 0.356 \\
\hline 34 & Pskov Region & 403 & 1,594 & -0.426 & 0.779 & 0.354 \\
\hline 35 & Republic of Chuvashia & 195 & 2,497 & -0.374 & 0.726 & 0.352 \\
\hline 36 & Kemerovo Region & 264 & 1,926 & -0.396 & 0.743 & 0.347 \\
\hline 37 & Kursk Region & 314 & 1,588 & -0.408 & 0.747 & 0.339 \\
\hline 38 & Voronezh Region & 246 & 1,755 & -0.391 & 0.725 & 0.334 \\
\hline 39 & Kaliningrad Region & 636 & 1,040 & -0.458 & 0.790 & 0.332 \\
\hline 40 & Republic of Komi & 2,495 & 609 & -0.555 & 0.884 & 0.329 \\
\hline 41 & Ryazan Region & 513 & 1,076 & -0.443 & 0.768 & 0.325 \\
\hline 42 & Kostroma Region & 499 & 1,069 & -0.441 & 0.763 & 0.323 \\
\hline 43 & Vologda Region & 140 & 2,228 & -0.351 & 0.671 & 0.320 \\
\hline 44 & Zabaikalsk Territory & 461 & 1,039 & -0.435 & 0.751 & 0.315 \\
\hline 45 & Republic of Udmurtia & 56 & 4,565 & -0.285 & 0.597 & 0.311 \\
\hline 46 & Tambov Region & 111 & 2,248 & -0.334 & 0.640 & 0.306 \\
\hline 47 & Kirov Region & 104 & 2,249 & -0.329 & 0.631 & 0.302 \\
\hline 48 & Irkutsk Region & 367 & 988 & -0.419 & 0.718 & 0.298 \\
\hline 49 & Murmansk Region & 101 & 1,557 & -0.328 & 0.598 & 0.270 \\
\hline 50 & Orenburg Region & 359 & 734 & -0.417 & 0.684 & 0.266 \\
\hline 51 & Belgorod Region & 174 & 1,030 & -0.366 & 0.631 & 0.264 \\
\hline 52 & Amur Region & 1,016 & 449 & -0.491 & 0.745 & 0.254 \\
\hline 53 & Magadan Region & 1,563 & 387 & -0.522 & 0.772 & 0.250 \\
\hline 54 & Ulyanovsk Region & 59 & 1,685 & -0.289 & 0.533 & 0.244 \\
\hline 55 & Smolensk Region & 81 & 1,171 & -0.312 & 0.546 & 0.235 \\
\hline 56 & Republic of Khakasia & 1,960 & 322 & -0.538 & 0.771 & 0.233 \\
\hline 57 & Orel Region & 54 & 1,471 & -0.283 & 0.512 & 0.229 \\
\hline 58 & Bryansk Region & 83 & 1,066 & -0.313 & 0.542 & 0.229 \\
\hline 59 & Kurgan Region & 116 & 835 & -0.337 & 0.563 & 0.226 \\
\hline 60 & Stavropol Territory & 94 & 920 & -0.323 & 0.546 & 0.224 \\
\hline 61 & Republic of Sakha (Yakutia) & 208 & 597 & -0.379 & 0.601 & 0.222 \\
\hline 62 & Penza Region & 54 & 1,134 & -0.283 & 0.495 & 0.211 \\
\hline 63 & Republic of Karelia & 37 & 1,191 & -0.256 & 0.450 & 0.194 \\
\hline 64 & Astrakhan Region & 67 & 591 & -0.299 & 0.474 & 0.175 \\
\hline 65 & Ivanovo Region & 74 & 486 & -0.306 & 0.469 & 0.164 \\
\hline 66 & Republic of Buryatia & 93 & 233 & -0.322 & 0.435 & 0.114 \\
\hline 67 & Kamchatka Territory & 264 & 137 & -0.396 & 0.483 & 0.088 \\
\hline 68 & Jewish Autonomous Area & 116 & 156 & -0.337 & 0.423 & 0.086 \\
\hline 69 & Republic of Mari El & 2 & 758 & -0.058 & 0.095 & 0.037 \\
\hline 70 & Republic of Altai & 1 & 82 & -0.027 & 0.029 & 0.003 \\
\hline 71 & Republic of Tuva & 35 & 8 & -0.252 & 0.130 & -0.122 \\
\hline
\end{tabular}

Note: ${ }^{a}$ The name of the region (Entity) is as of 2013

${ }^{\mathrm{b}}$ Predictions based on the result of the random-effects model [5] in Table 8

Source: Authors' computation 
Table 10. Robustness check of the synergy effect of FDI and regional R\&D potential ${ }^{a}$

(a) Estimation using the natural logarithm of the technological innovation costs per R\&D staff member (lnINNOVCOST) as the R\&D variable

\begin{tabular}{|c|c|c|c|c|c|c|c|c|c|c|}
\hline \multirow{4}{*}{$\begin{array}{l}\frac{\text { Estimation period }}{\text { Target regions }} \\
\text { Estimator }^{\mathrm{b}} \\
\text { Model }\end{array}$} & \multirow{2}{*}{\multicolumn{10}{|c|}{$\frac{1996-2011}{\text { All } 71 \text { regions }}$}} \\
\hline & \multirow{2}{*}{\multicolumn{5}{|c|}{ All 7}} & & & & & \\
\hline & & & & & & \multicolumn{5}{|c|}{ system GMM } \\
\hline & [1] & [2] & [3] & {$[4]$} & [5] & {$[6]$} & [7] & {$[8]$} & [9] & {$[10]$} \\
\hline \multicolumn{11}{|l|}{${ }^{\prime}$ DI variables ${ }^{c}$} \\
\hline $\operatorname{lnFDIANN}$ & $\begin{array}{l}-0.0689^{* * *} \\
(0.021)\end{array}$ & & & & & $\begin{array}{l}-0.0269^{* *} \\
(0.014)\end{array}$ & & & & \\
\hline $\operatorname{lnFDI3AVE}$ & & $\begin{array}{l}-0.0959^{* * *} \\
(0.025)\end{array}$ & & & & & $\begin{array}{l}-0.0387^{* *} \\
(0.017)\end{array}$ & & & \\
\hline $\ln F D I P C$ & & & $\begin{array}{l}-0.0619^{* * *} \\
(0.024)\end{array}$ & & & & & $\begin{array}{l}-0.0282^{*} \\
(0.015)\end{array}$ & & \\
\hline $\ln C U M F D I$ & & & & $\begin{array}{l}0.0335 \\
(0.034)\end{array}$ & & & & & $\begin{array}{l}0.2143^{* *} \\
(0.092)\end{array}$ & \\
\hline $\ln C U M F D I P C$ & & & & & $\begin{array}{l}-0.0411 \\
(0.032)\end{array}$ & & & & & $\begin{array}{c}0.0058 \\
(0.026)\end{array}$ \\
\hline \multicolumn{11}{|l|}{$R \& D$ variable } \\
\hline $\ln I N N O V C O S T$ & $\begin{array}{l}-0.0432^{* *} \\
(0.018)\end{array}$ & $\begin{array}{l}-0.0699^{* * * *} \\
(0.023)\end{array}$ & $\begin{array}{l}-0.0008 \\
(0.007)\end{array}$ & $\begin{array}{l}-0.0471 \\
(0.034)\end{array}$ & $\begin{array}{r}-0.0169 \\
(0.015)\end{array}$ & $\begin{array}{l}-0.0194 \\
(0.013)\end{array}$ & $\begin{array}{l}-0.0275^{*} \\
(0.016)\end{array}$ & $\begin{array}{l}0.0028 \\
(0.008)\end{array}$ & $\begin{array}{l}-0.0515 \\
(0.039)\end{array}$ & $\begin{array}{l}-0.0185 \\
(0.013)\end{array}$ \\
\hline \multicolumn{11}{|c|}{ Interaction term of FDI and R\&D variables ${ }^{c}$} \\
\hline$F D I \times \operatorname{lnINNOVCOST}$ & $\begin{array}{l}0.0059^{* * *} \\
(0.002)\end{array}$ & $\begin{array}{l}0.0086^{* * *} \\
(0.002)\end{array}$ & $\begin{array}{l}0.0052^{* * *} \\
(0.002)\end{array}$ & $\begin{array}{l}0.0054^{*} \\
(0.003)\end{array}$ & $\begin{array}{l}0.00644^{* *} \\
(0.003)\end{array}$ & $\begin{array}{l}0.0031^{* * *} \\
(0.001)\end{array}$ & $\begin{array}{l}0.0037^{* * *} \\
(0.001)\end{array}$ & $\begin{array}{l}0.00322^{* *} \\
(0.001)\end{array}$ & $\begin{array}{r}0.0050 \\
(0.003) \\
\end{array}$ & $\begin{array}{l}0.0047^{* * * *} \\
(0.002)\end{array}$ \\
\hline $\bar{N}$ & 931 & 951 & 932 & 960 & 960 & 761 & 797 & 761 & 809 & 809 \\
\hline Wald test $\left(\chi^{2}\right)^{\mathrm{d}}$ & $2154.96^{* * *}$ & $2267.64^{* * *}$ & $2078.92^{* * *}$ & $2582.39^{* * *}$ & $2330.20^{* * *}$ & $1786.34^{* * *}$ & $2340.87^{* * *}$ & $1915.90^{* * *}$ & $2530.52^{* * *}$ & $2679.56^{* * * *}$ \\
\hline
\end{tabular}

(b) Estimation using the natural logarithm of the number of research and higher education institutions (InINSTITUTE) as the R\&D variable

\begin{tabular}{|c|c|c|c|c|c|c|c|c|c|c|}
\hline \multirow{3}{*}{$\begin{array}{l}\text { Estimation period } \\
\text { Target regions } \\
\text { Estimator } \\
{ }^{\mathrm{b}}\end{array}$} & \multicolumn{10}{|c|}{ 1996-2011 } \\
\hline & \multicolumn{10}{|c|}{ All 71 regions } \\
\hline & & & $\mathrm{RE}$ & & & & & ystem GMM & & \\
\hline Model & [11] & {$[12]$} & [13] & [14] & [15] & [16] & {$[17]$} & {$[18]$} & [19] & {$[20]$} \\
\hline \multicolumn{11}{|l|}{ FDI variables $^{c}$} \\
\hline InFDIANN & $\begin{array}{l}-0.0295^{* *} \\
(0.015)\end{array}$ & & & & & $\begin{array}{r}-0.0273 \\
(0.021)\end{array}$ & & & & \\
\hline $\ln F D I 3 A V E$ & & $\begin{array}{c}-0.0340{ }^{*} \\
(0.019)\end{array}$ & & & & & $\begin{array}{l}-0.0651^{* *} \\
(0.026)\end{array}$ & & & \\
\hline $\ln F D I P C$ & & & $\begin{array}{l}-0.0288 \text { * } \\
(0.015)\end{array}$ & & & & & $\begin{array}{r}-0.0199 \\
(0.018)\end{array}$ & & \\
\hline $\ln C U M F D I$ & & & & $\begin{array}{c}-0.0020 \\
(0.036)\end{array}$ & & & & & $\begin{array}{r}0.0131 \\
(0.058)\end{array}$ & \\
\hline $\ln C U M F D I P C$ & & & & & $\begin{array}{r}-0.0255 \\
(0.021)\end{array}$ & & & & & $\begin{array}{l}-0.1642^{* * *} \\
(0.035)\end{array}$ \\
\hline \multicolumn{11}{|l|}{$R \& D$ variable } \\
\hline InINSTITUTE & $\begin{array}{l}-0.08844^{*} \\
(0.053)\end{array}$ & $\begin{array}{l}-0.1249^{* *} \\
(0.056)\end{array}$ & $\begin{array}{r}-0.0181 \\
(0.044)\end{array}$ & $\begin{array}{l}-0.3190^{* * *} \\
(0.090)\end{array}$ & $\begin{array}{l}-0.0775{ }^{*} \\
(0.041)\end{array}$ & $\begin{array}{l}0.0231 \\
(0.086)\end{array}$ & $\begin{array}{r}-0.1088 \\
(0.109)\end{array}$ & $\begin{array}{l}0.0788 \\
(0.080)\end{array}$ & $\begin{array}{l}-0.3387^{* *} \\
(0.156)\end{array}$ & $\begin{array}{l}-0.1752^{* *} \\
(0.078)\end{array}$ \\
\hline \multicolumn{11}{|c|}{ Interaction term of FDI and $R \& D$ variables ${ }^{c}$} \\
\hline$F D I \times \operatorname{lnINSTITUTE}$ & $\begin{array}{l}0.0097^{* *} \\
(0.004)\end{array}$ & $\begin{array}{l}0.01366^{* *} \\
(0.006)\end{array}$ & $\begin{array}{l}0.00944^{* *} \\
(0.004)\end{array}$ & $\begin{array}{l}0.0262 \\
(0.008)\end{array}$ & $\begin{array}{l}0.0207 \text { *** } \\
(0.005)\end{array}$ & $\begin{array}{l}0.0110^{*} \\
(0.006)\end{array}$ & $\begin{array}{l}0.0208^{* * *} \\
(0.008)\end{array}$ & $\begin{array}{l}0.0087^{*} \\
(0.005)\end{array}$ & $\begin{array}{l}0.0432^{* * *} \\
(0.016)\end{array}$ & $\begin{array}{l}0.0678 \text { *** } \\
(0.011)\end{array}$ \\
\hline$N$ & 933 & 958 & 934 & 977 & 977 & 828 & 803 & 828 & 906 & 906 \\
\hline Wald test $\left(\chi^{2}\right)^{\mathrm{d}}$ & $2493.04^{* * * *}$ & $2626.94^{* * *}$ & $2280.288^{* * * *}$ & $3059.16^{* * * *}$ & $3354.84^{* * * *}$ & $1779.03^{* * * *}$ & $2054.32^{* * *}$ & $1810.16^{* * *}$ & $2891.04^{* * * *}$ & $2369.22 * * *$ \\
\hline
\end{tabular}




\begin{tabular}{|c|c|c|c|c|c|c|c|c|c|c|}
\hline \multirow{4}{*}{$\begin{array}{l}\text { Estimation period } \\
\text { Target regions } \\
\text { Estimator }{ }^{\text {b }} \\
\text { Model }\end{array}$} & \multicolumn{10}{|c|}{$1996-2011$} \\
\hline & \multicolumn{10}{|c|}{ All 71 regions } \\
\hline & & & $\mathrm{RE}$ & & & & & ystem GMM & & \\
\hline & [21] & {$[22]$} & [23] & [24] & {$[25]$} & {$[26]$} & {$[27]$} & {$[28]$} & {$[29]$} & {$[30]$} \\
\hline \multicolumn{11}{|l|}{$\overline{\text { FDI variables }}{ }^{\mathrm{c}}$} \\
\hline $\ln F D I A N N$ & $\begin{array}{l}-0.1487^{* * * *} \\
(0.041)\end{array}$ & & & & & $\begin{array}{r}0.0642 \\
(0.062)\end{array}$ & & & & \\
\hline $\ln F D I 3 A V E$ & & $\begin{array}{l}-0.1597^{* * *} \\
(0.059)\end{array}$ & & & & & $\begin{array}{l}0.0673 \\
(0.078)\end{array}$ & & & \\
\hline $\ln F D I P C$ & & & $\begin{array}{l}-0.1454^{* * *} \\
(0.050)\end{array}$ & & & & & $\begin{array}{l}0.0671 \\
(0.057)\end{array}$ & & \\
\hline $\ln C U M F D I$ & & & & $\begin{array}{r}-0.0632 \\
(0.076)\end{array}$ & & & & & $\begin{array}{l}0.2133^{* *} \\
(0.102)\end{array}$ & \\
\hline $\ln C U M F D I P C$ & & & & & $\begin{array}{l}-0.2030^{* * *} \\
(0.062)\end{array}$ & & & & & $\begin{array}{r}0.0744 \\
(0.111)\end{array}$ \\
\hline \multicolumn{11}{|l|}{$R \& D$ variable } \\
\hline $\operatorname{lnSTUDENT}$ & $\begin{array}{l}-0.2957^{* * * *} \\
(0.073)\end{array}$ & $\begin{array}{l}-0.3013^{* * *} \\
(0.099)\end{array}$ & $\begin{array}{l}-0.11288^{* * *} \\
(0.042)\end{array}$ & $\begin{array}{l}-0.3410^{*} \\
(0.175)\end{array}$ & $\begin{array}{l}-0.18222^{* * *} \\
(0.054)\end{array}$ & $\begin{array}{r}-0.0127 \\
(0.129)\end{array}$ & $\begin{array}{r}-0.0775 \\
(0.123)\end{array}$ & $\begin{array}{r}-0.0602 \\
(0.075)\end{array}$ & $\begin{array}{c}0.0536 \\
(0.216)\end{array}$ & $\begin{array}{r}-0.0536 \\
(0.085)\end{array}$ \\
\hline \multicolumn{11}{|c|}{ Interaction term of FDI and $R \& D$ variables ${ }^{c}$} \\
\hline$F D I \times \operatorname{lnSTUDENT}$ & $\begin{array}{l}0.0257^{* * * *} \\
(0.007)\end{array}$ & $\begin{array}{l}0.0285^{* * *} \\
(0.010)\end{array}$ & $\begin{array}{l}0.0250 \text { *** } \\
(0.009)\end{array}$ & $\begin{array}{l}0.0259^{* *} \\
(0.013)\end{array}$ & $\begin{array}{l}0.0423 \\
(0.011)\end{array}$ & $\begin{array}{c}-0.0093 \\
(0.010)\end{array}$ & $\begin{array}{r}-0.0103 \\
(0.013)\end{array}$ & $\begin{array}{l}-0.0096 \\
(0.009)\end{array}$ & $\begin{array}{r}-0.0189 \\
(0.019)\end{array}$ & $\begin{array}{r}-0.0063 \\
(0.018)\end{array}$ \\
\hline $\bar{N}$ & 933 & 958 & 934 & 977 & 977 & 828 & 803 & 828 & 906 & 906 \\
\hline Wald test $\left(\chi^{2}\right)^{\mathrm{d}}$ & $2361.48^{* * * *}$ & $2341.28^{* * *}$ & $2336.39^{* * *}$ & $2327.58^{* * *}$ & $2264.36^{* * *}$ & $1369.20^{* * *}$ & $2054.27^{* * *}$ & $1508.61^{* * *}$ & $2164.46^{* * *}$ & $2415.37^{* * *}$ \\
\hline
\end{tabular}

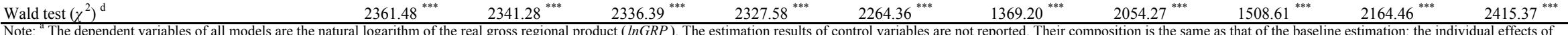
regions and the time fixed effects are also controlled. Figures in parentheses beneath regression coefficients are robust standard errors. $* * *, * *$, and * denote statistical significance at the $1 \%, 5 \%$, and $10 \%$ levels, respectively.

${ }^{\mathrm{b}} \mathrm{RE}$ and system GMM denote random-effects estimator and system generalized method-of-moments (GMM) estimator, respectively.

${ }^{\circ}$ The random-effects models adopt one-year lagged FDI variables and their interaction terms, while the system GMM dynamic models endogenize non-lagged FDI variables and their interaction terms, assuming their two-year lag structure.

${ }^{\mathrm{d}}$ Null hypothesis: All coefficients are zero.

Source: Authors' estimation. See Table 5 for the definitions and descriptive statistics of the variables used in the estimation. 